\title{
Genetic Organization of Junin Virus, the Etiological Agent of Argentine Hemorrhagic Fever
}

\author{
VICTOR ROMANOWSKI
}

\section{INTRODUCTION}

Most of the data on the genome organization of Junin virus presented in this chapter come from our laboratory and include results that are at the stage of manuscript preparation. Molecular cloning and sequencing studies on this human pathogenic arenavirus were focused on the $S$ RNA, which codes for the major structural proteins.

In the first part of this chapter the biochemical structure of Junin virus is reviewed after a short historical background. In some instances, where information specific for Junin virus is ambiguous, references are made to data published for other arenaviruses.

\section{HISTORICAL CONSIDERATIONS}

The symptoms and clinical forms of Argentine hemorrhagic fever (AHF) were first described by Aribalzaga (1955) after the observations of the 1953 and 1954 epidemic outbreaks in Bragado, Buenos Aires. The viral etiology of the disease was established in 1958 by two groups led by Parodi and Pirosky, respectively, who isolated the virus from the blood

VICTOR ROMANOWSKI - Instituto de Bioquimica y Biologia Molecular, Departamento de Ciencias Biológicas, Facultad de Ciencias Exactas, Universidad Nacional de La Plata, 1900 La Plata, Argentina.

The Arenaviridae, edited by Maria S. Salvato. Plenum Press, New York, 1993. 
of patients and organs obtained from necropsies at the city of Junin Regional Hospital (Parodi et al., 1958; Pirosky et al., 1959). The etiological agent was named Junin virus after the geographical site of its initial isolation.

At that time the epidemic outbreaks were restricted to an area of $16,000 \mathrm{~km}^{2}$. Since then, AHF has spread to the provinces of Cordoba, Santa Fe, and La Pampa, increasing the endemic area to five times its initial size by 1975 (Maiztegui and Sabattini, 1977). In 1986 the progressive extension of the endemic area was reported to cover more than $120,000 \mathrm{~km}^{2}$ of the richest farming land in Argentina with more than 2 million inhabitants (Maiztegui et al., 1986). Consequently, the disease has had considerable impact on the welfare and economy of Argentina and has stimulated research on AHF and Junin virus to solve this sanitary problem.

As is obvious, early research on AHF was focused on reproducing the disease in animal models (Boxaca et al., 1961; 1965) and establishing serological relationships with other viruses (Mettler et al., 1963).

The propagation of Junin virus in tissue culture (Mettler et al., 1961; Martinez Segovia et al., 1967; 1974; Murphy et al., 1970; Lascano and Berria, 1970) allowed a better morphological and serological characterization of the virus.

In 1965 Junin virus was found to be related to Tacaribe virus and Machupo virus, the etiological agent of Bolivian hemorrhagic fever, by serological means (Johnson et al., 1973). These viruses and, subsequently, others that were isolated on the American continent, were grouped into what became known as the Tacaribe complex. All members of the Tacaribe complex were found to share the morphological features of LCM and Machupo viruses (Murphy et al., 1970). The relatedness of these viruses was further evidenced by the cross reactivity between antigens of LCM and antisera to viruses of the Tacaribe complex (Rowe et al., 1970a), leading to the establishment of a new taxonomic group known as Arenaviridae (Rowe et al., 1970b; Pfau et al., 1974).

Considerable effort has been devoted to study of the pathobiology of Junin virus both in human patients and animal models, as reviewed by Weissenbacher and Damonte (1983). However, the biochemical characterization of Junin virus and the molecular biology of the infection have received less attention in the same period, as is apparent from the list of published results.

\section{STRUCTURAL COMPONENTS OF JUNIN VIRUS}

\section{A. Virus Growth and Purification}

The biochemical studies on Junin virus were initially precluded by the low titers obtained in tissue cultures (Martinez Segovia et al., 1967). 
In 1974 Martinez Segovia et al. described a convenient procedure for the production of Junin virus in BHK-21 cell cultures. Daily changes of the supernatant culture medium resulted in maximum virus yields at days 4,5 , and 6 postinfection quantitated as $10^{6}$ to $10^{7} \mathrm{LD}_{50} / \mathrm{ml}$ by intracerebral inoculation in suckling mice. Several methods have been used to concentrate the viral particles, including an aqueous biphasic polymer system (Martinez Segovia and Diaz, 1968), precipitation with protamine sulfate (Coto and Parodi, 1968) or ammonium sulfate (Help et al., 1970), and ultracentrifugation (Anon et al., 1976). The latter method has been the most popular owing to its simplicity and the good recovery of virus infectivity. Junin virus purification described by Anon et al. (1976) included two successive sucrose gradient steps and yielded virus particles sufficiently pure for RNA composition analysis. However, this type of gradient did not eliminate the bovine serum proteins that came from the tissue culture medium. A more efficient purification procedure using a potassium tartrate-glycerol step gradient and a cesium chloride continuous gradient produced virions completely devoid of foreign proteins as judged by Coomassie blue staining or in vitro iodination (Grau et al., 1981; Romanowski, 1981). These data suggest that alternative purification procedures should always include a high-salt step to strip off the contaminating serum proteins.

Buoyant densities of virus particles from different sources were reported to range from 1.12 to $1.17 \mathrm{~g} / \mathrm{cm}^{3}$ in sucrose gradients (Coto et al., 1972; Johnson et al., 1973; Anon et al., 1976). The reason for this variation could be more related to the different amounts of contaminating proteins than to the pleomorphic nature of the viruses. Purified Junin virus particles float at a density of $1.20 \mathrm{~g} / \mathrm{cm}^{3}$ in $\mathrm{CsCl}$ (Romanowski, 1981).

\section{B. Proteins}

The structural polypeptides of Junin virus have been examined in preparations of virus particles metabolically labeled with ${ }^{3} \mathrm{H}$ or ${ }^{14} \mathrm{C}$ amino acids. In these studies the $\mathrm{MC} 2$ strain of Junin virus was grown in BHK-21 cell monolayers and recovered from the supernatant culture medium. Martinez Segovia and De Mitri (1977) reported six structural proteins with estimated molecular weights of $91,71,64,52,38$, and 25 $\mathrm{kDa}$. The $91-\mathrm{kDa}, 71-\mathrm{kDa}, 52-\mathrm{kDa}$, and $38-\mathrm{kDa}$ polypeptides were also labeled with $\left[{ }^{14} \mathrm{C}\right]$ glucosamine.

On the other hand, Grau et al. (1981) showed a more simple protein pattern for Junin virus particles ( $\mathrm{MC} 2$ and $\mathrm{XJCl} 3$ strains). Three polypeptides with molecular weights of 60,44 , and $35 \mathrm{kDa}$ were labeled with $\left[{ }^{35} \mathrm{~S}\right]$ methionine or $\left[{ }^{3} \mathrm{H}\right]$ leucine. When $\left[{ }^{3} \mathrm{H}\right]$ glucosamine was used as radioactive precursor, the $35-\mathrm{kDa}$ polypeptide was intensely labeled and smaller amounts of $\left[{ }^{3} \mathrm{H}\right]$ glucosamine were found in the $44-\mathrm{kDa}$ protein. In this study the SDS-PAGE pattern of labeled proteins remained un- 
changed throughout the purification procedure, rendering coincident patterns of bands in the stained and labeled gels at the last purification step.

The apparent discrepancy on the protein composition of Junin virus published by two laboratories is not very big if one considers that both report two major polypeptides: a $64-\mathrm{kDa}$ or $60-\mathrm{kDa}$ sharp and most prominent band and a $38-\mathrm{kDa}$ or $35-\mathrm{kDa}$ broad glycoprotein band. The 52-kDa glycoprotein in Martinez Segovia and De Mitri's paper (1977) could well be the 44-kDa polypeptide reported by Grau et al. (1981), since different polyacrylamide gel electrophoresis systems were employed in both studies. The $91-\mathrm{kDa}$ glycoprotein is thought to be an aggregation artifact in the gel system used by Martinez Segovia and De Mitri (1977). They also report that the proportion of the $25-\mathrm{kDa}$ polypeptide is variable and, sometimes, is not detected. A polypeptide of a similar size has been shown in some preparations of other arenaviruses (Clegg and Lloyd, 1983; Young et al., 1987) and might be a proteolytic cleavage product of the $60-\mathrm{kDa}$ protein. And, at last, the $72-\mathrm{kDa}$ glycosylated polypeptide could reflect the incorporation of the uncleaved glycoprotein precursor GPC (Rustici, 1984; De Mitri and Martinez Segovia, 1985) into virions. Buchmeier et al. (1987) have occasionally observed traces of GPC in purified LCM virions.

After all, several laboratories have produced data for other arenaviruses that were also dissimilar to some extent (Gard et al., 1977; Gangemi et al., 1978; Ramos et al.,, 1972; Vezza et al., 1977; Young et al., 1981; Kiley et al., 1981; Clegg and Lloyd, 1983).

\section{Nucleocapsids}

Electron microscopic studies have not shown an electron-dense, highly structured nucleocapsid in the arenavirus particles. However, when virions disrupted with nonionic detergents, such as Nonidet P-40, were centrifuged to equilibrium in $\mathrm{CsCl}$ gradients, a ribonucleoprotein structure banded at densities of $1.31-1.37 \mathrm{~g} / \mathrm{cm}^{3}$. Examination of these structures derived from Tacaribe virus under the electron microscope revealed closed circular structures which appeared as strings of beads (Palmer et al., 1977). The length of the circles fell into two predominant size classes, $640 \mathrm{~nm}$ and $1300 \mathrm{~nm}$, which most likely correspond to both genomic RNAs known to be roughly $3.5 \mathrm{~kb}$ (S RNA) and $7 \mathrm{~kb}$ (L RNA) in length (Franze-Fernandez et al., 1987; Iapalucci et al., 1989 a,b). Vezza et al. (1977) also reported circular filamentous structures $10-15 \mathrm{~nm}$ in diameter for Pichinde virus ribonucleoproteins. More recently, Young and Howard (1983) were able to reveal a more detailed structure consisting of globular 4- to 5-nm subunits that appeared to fold into helical fiber structures $12-15 \mathrm{~nm}$ in diameter.

Martinez-Segovia and De Mitri (1977) reported that Junin virions 
disrupted with $2 \%$ Triton $\mathrm{X}-100$ and banded in a $\mathrm{CsCl}$ gradient contained RNA associated with the major $64-\mathrm{kDa}$ structural protein. When analyzed by ultracentrifugation in sucrose gradients, Junin virus treated with $0.12 \%$ Nonidet $\mathrm{P}-40$ was shown to dissociate into a soluble protein fraction, containing only the glycoproteins, and a fast sedimenting $(>170$ S) nucleoprotein component containing RNA and only the 60$\mathrm{kDa}$ major structural polypeptide (Grau et al., 1981; Romanowski, 1981 ). This $60-\mathrm{kDa}$ polypeptide will be called $\mathrm{N}$ (for nucleocapsid protein) throughout the rest of this text.

The $\mathrm{N}$ protein as well as its proteolytic cleavage products occurring in infected cells have been shown to react in complement fixation (CF) tests (De Mitri and Martinez Segovia, 1980). This test was earlier used to examine serological interrelationships between members of the Arenaviridae family (Rowe et al., 1970a; Casals et al., 1975). Viruses belonging to the New World arenavirus group or Tacaribe complex exhibit more extensive cross-reactivities than those shown between members of this group and the Old World arenaviruses LCM and Lassa.

Using immunoprecipitation of radiolabeled virus proteins with homologous and heterologous antisera, it was demonstrated that the $\mathrm{N}$ protein was responsible for the antigenic cross-reactivity among the Tacaribe complex arenaviruses (Buchmeier and Oldstone, 1978). Moreover, among the monoclonal antibodies raised against Pichinde virus, several were shown to react with one or more heterologous viruses and one of them cross-reacted broadly with five New World and two Old World arenaviruses (Buchmeier et al., 1981). Although, the epitopes responsible for the serological cross-reactivity among $\mathrm{N}$ proteins of different arenaviruses have not been identified, cloning and sequencing of Pichinde and LCM S RNA showed a high degree of conservation in several regions of the $\mathrm{N}$ protein amino acid sequence (Romanowski and Bishop, 1985).

\section{Viral Envelope}

Electron microscopic studies show round or oval particles of Junin virus surrounded by a lipid bilayer with 10 -nm surface projections or spikes (Lascano and Berria, 1974). The viral envelope is acquired during virus budding at the cellular plasma membrane (Murphy et al., 1970; Murphy and Whitfield, 1975; Lascano and Berria, 1974). This aspect of Junin virus morphogenesis is supported by comparative data on the phospholipid composition of viruses and host cells (Rosas et al., 1988; Rosas, 1984).

The solubilization of the viral envelope using nonionic detergents removes the 35- to 38-kDa major glycoprotein /Grau et al., 1981; Cresta et al., 1980). This protein is exposed on the surface of the viral envelope as shown by in vitro iodination of intact highly purified virions (Roman- 
owski, 1981). Removal of glycoproteins by protease treatment of Pichinde virus coincided with the disappearance of spike structures on the virus envelope (Vezza et al., 1977). By analogy, it is deduced that the 35to $38-\mathrm{kDa}$ glycoprotein builds the spikes on the surface of Junin virions.

Pulse-chase experiments of Junin virus-infected BHK-21 cells have demonstrated that a $34-\mathrm{kDa}$ glycoprotein is formed from a $57-\mathrm{kDa}$ precursor. No other glucosamine-labeled polypeptides have been observed during the processing of the $57-\mathrm{kDa}$ protein (GPC?) (Rustici, 1984). However, in most of the gel electrophoretic analyses of mature virus proteins the major glycoprotein band appears often as a doublet peaking at $34 \mathrm{kDa}$ and $39 \mathrm{kDa}$ (Grau et al., 1981). This observation has been $a$ priori attributed to a difference in the glycosylation of a single polypeptide, but has not been confirmed by peptide mapping. In relation to this possibility, it is worth mentioning than only one structural glycoprotein has been reported for Tacaribe virus, a very close serological relative of Junin virus (Gard et al., 1977; Boersma et al., 1982). More recent studies have indicated that the broad glycoprotein band found in Tacaribe virions actually contains two different polypeptide species, one of which is partially lost during some purification procedures using high-salt solutions (Burns and Buchmeier, personal communication, and see their Chapter 2, this volume).

The antigenic potential of Junin virus major glycoprotein has been explored by Cresta et al. (1980), who have shown that it elicits neutralizing antibodies. In this respect, this glycoprotein resembles the behavior of LCM virus GP-1 and Lassa virus G1. The inoculation of the purified protein protected guinea pigs from a challenge with $10 \mathrm{LD}_{50}$ of a pathogenic Junin virus strain. Therefore, it is reasonable to expect that the cloned glycoprotein gene, or a fragment of it, expressed in a suitable host-vector system could be used as a candidate vaccine.

Regarding the 44-kDa minor glycoprotein of Junin virus, no data are available on its localization in the viral envelope or its relationship to the GPC.

\section{E. Viral RNA}

Indirect evidence arguing for an RNA genome in Junin virus was published in 1969 (Martinez Segovia and Graziola, 1969; Coto and Vombergar, 1969). Only after a large-scale virus growth was optimized (Martinez Segovia et al., 1974; Anon et al., 1976) was biochemical analysis of the genome possible.

The genome of Junin virus consists of two single-stranded RNA species described in the original report by Anon et al. (1976) as 33S and 25S. Their molecular weights were estimated to be $2.4 \times 10^{6}$ and 1.3 $\times 10^{6}$, respectively, from the electrophoretic mobilities in $2.7 \%$ polyacrylamide gels. The apparent molecular weights of the two genomic 
RNA species, known now as $\mathrm{L}$ (large) and $\mathrm{S}$ (small), estimated from their mobility in denaturing agarose gels using $\mathrm{CH}_{3} \mathrm{HgOH}$, are very similar to the ones previously described (Romanowski et al., unpublished results).

In addition to the genomic RNA, 28S, 18S, and 4-6S RNAs of cellular origin were found to account for $50 \%$ or even more of the $\left[{ }^{3} \mathrm{H}\right]$ uridine incorporated into the viruses. These RNAs come from the ribosomes and tRNAs incorporated into the virions in quite variable proportions in different virus preparations (Rawls and Leung, 1979).

Electron micrographs normally show that variable numbers of ribosomal granules are packaged in virions that range in diameter from 50 to $300 \mathrm{~nm}$ (Murphy and Whitfield, 1975). Using cells with a ts mutation that affected the 60S ribosomal subunit, Leung and Rawls (1977) demonstrated that Pichinde virus-associated ribosomes were not required for virus replication. In these experiments, the virus was first grown in the ts cells and its progeny, containing ts ribosomes, was subsequently replicated successfully in wild-type cells at either the permissive or the nonpermissive temperature.

On the other hand, Mannweiler and Lehmann-Grube (1973) have observed small ribosome-less LCM virus particles and suggested that these were the truly infective units, whereas the larger particles containing the electron-dense granules were not infectious. A large proportion of similar 60-nm particles were observed in tissues from AHF patients in addition to the more classical larger particles with ribosomes (Maiztegui et al., 1975). Consistent with these data, filtration of Junin virus through membranes with different pore-size distributions suggested that infectivity was associated with 40 to $70 \mathrm{~nm}$ particles (Coto et al., 1972).

In addition to the variability in the amount of ribosomal RNAs between different virus populations (preparations) and among virions within the same population, a variability in the L RNA to $S$ RNA ratio can be noted in the literature reports (see Table I). In all the arenaviruses studied, S RNA molecules are present in excess relative to the L RNA.

TABLE I. Molar Ratios of $\mathrm{L}$ and S RNAs in Purified Virions ${ }^{a}$

\begin{tabular}{lccl}
\hline Virus & $\begin{array}{c}\text { Radioactivity ratio } \\
\text { (L-RNA/S-RNA) }\end{array}$ & $\begin{array}{c}\text { Molar ratio } \\
\text { (S-RNA/L-RNA) }\end{array}$ & \multicolumn{1}{c}{ Ref. } \\
\hline Junin & 1.3 & 1.5 & Anon et al. (1976) \\
LCM & $0.7-0.4$ & $2.9-5.0$ & Pedersen (1973) \\
LCM & 0.55 & 3.6 & Romanowski and Bishop (1983) \\
Pichindé & 1.0 & 2.0 & Carter et al. (1973) \\
Pichindé & 1.1 & 1.8 & Farber and Rawls (1975) \\
Pichindé & $<1.0$ & $>2.0$ & Dutko et al. (1976) \\
Pichindé & $<1.0$ & $>2.0$ & Vezza et al. (1978) \\
\hline
\end{tabular}

${ }^{a}$ The incorporation of radioactivity precursors $\left(\left[{ }^{32} \mathrm{P}\right]\right.$-orthophosphate or $\left[{ }^{3} \mathrm{H}\right]$-uridine $)$ into the different RNA species of purified virions was used to calculate the relative molar amounts of $L$ and S RNA. To this end, the molecular size ratio of $L$ to S RNA was considered to be roughly 2 and the proportion of uridine in the RNAs was assumed to be $25 \%$. 
The nonequimolar proportions of $L$ and $S$ RNAs could be explained through the formation of virions containing multiple copies of viral nucleocapsids, or different amounts of virions that have packaged $\mathrm{S}$ or $\mathrm{L}$ nucleocapsid only. A not very accurate packaging mechanism for the arenavirus particles would not be surprising since different amounts of ribosomes are included in the virions budding from the infected cells. In fact, the formation of arenaviruses that are genetically diploid for $S$ RNA has been demonstrated in the progeny of cells coinfected with complementing ts mutants of two LCM virus strains (Romanowski and Bishop, 1983).

The formation of virus particles was also studied from a kinetic perspective using a double isotope label technique (Lopez et al., 1986). In this approach, Junin virus-infected BHK- 21 cells were first labeled with $\left[{ }^{14} \mathrm{C}\right]$ uridine until a constant specific activity was reached in the RNA of the virions recovered from the supernatant medium. Only then the medium was changed to one containing both $\left[{ }^{14} \mathrm{C}\right]$ uridine (with a specific activity equal to the one used in the previous step) and $\left[{ }^{3} \mathrm{H}\right]-$ uridine. The variation of the ${ }^{3} \mathrm{H} /{ }^{14} \mathrm{C}$ ratio in the virus RNA collected at different time intervals after the addition of $\left[{ }^{3} \mathrm{H}\right]$ uridine was used to calculate the generation time of a virus particle. This time was estimated to be $5 \mathrm{hr}$ for Junin virus and includes the replication, assembly, and release of a virion to the medium at the stationary phase of virus growth.

The same authors also demonstrated that actinomycin D affects neither arenavirus RNA synthesis nor virus yields in tissue culture, when the times of exposure to the drug are shorter than the time when cell-toxic effects become evident. These results indicate that continuous host transcription is not required for replication of the arenaviruses.

\section{JUNIN VIRUS S RNA}

\section{A. Molecular Cloning and Sequence Analysis of Junin Virus S RNA}

As most of the biochemical data were derived from the MC2 strain of Junin virus, it was also chosen for the first cDNA cloning and sequencing studies. RNA extracted from plaque-cloned virus grown in BHK-21 cells was used for cDNA synthesis in several rounds. Based on the published $3^{\prime}$ end sequence of different arenaviruses (Auperin et al., 1982 ; i.e., GCGUGUCACCUAGGAUCCG), a complementary synthetic oligodeoxyribonucleotide was used to prime cDNA synthesis in a protocol similar to the one described by Gubler and Hoffman (1983). Double-stranded cDNA was inserted into pUC plasmid vectors and cloned in Escherichia coli DH5 $\alpha$. Pnitial screening of the cDNA library using a short copy cDNA probe (Bishop et al., 1982) yielded clones that belonged to both $\mathrm{L}$ and $\mathrm{S}$ viral RNAs as shown by Northern blot analysis. 
Analogous results have also been observed during the cloning of LCMWE S RNA (Romanowski and Bishop, 1985). The recovery of L cDNA clones using an S RNA primer was presumably due to the similarity of the $L$ and $S 3^{\prime}$ end sequences.

Since full-length cDNA clones were not obtained, a primer complementary to the distal end of the first set of $S$ RNA clones was used for a second round of cDNA synthesis and cloning (see Fig. 1). A third round of cDNA synthesis and cloning was necessary to reach the 5 ' end of Junin virus $S$ RNA.

The DNA sequences of partially overlapping clones were determined according to the method of Sanger et al. (1977). Some regions of these clones were also sequenced using the chemical modification method of Maxam and Gilbert (1980). Nucleotide sequences in the overlapping regions of the inserts were identical (Fig. 1). The $5^{\prime}$ and $3^{\prime}$ terminal nucleotide sequences were carefully confirmed in additional experiments. The $5^{\prime}$ end of the $S$ RNA was confirmed by primer extension using an oligonucleotide complementary to a sequence near this
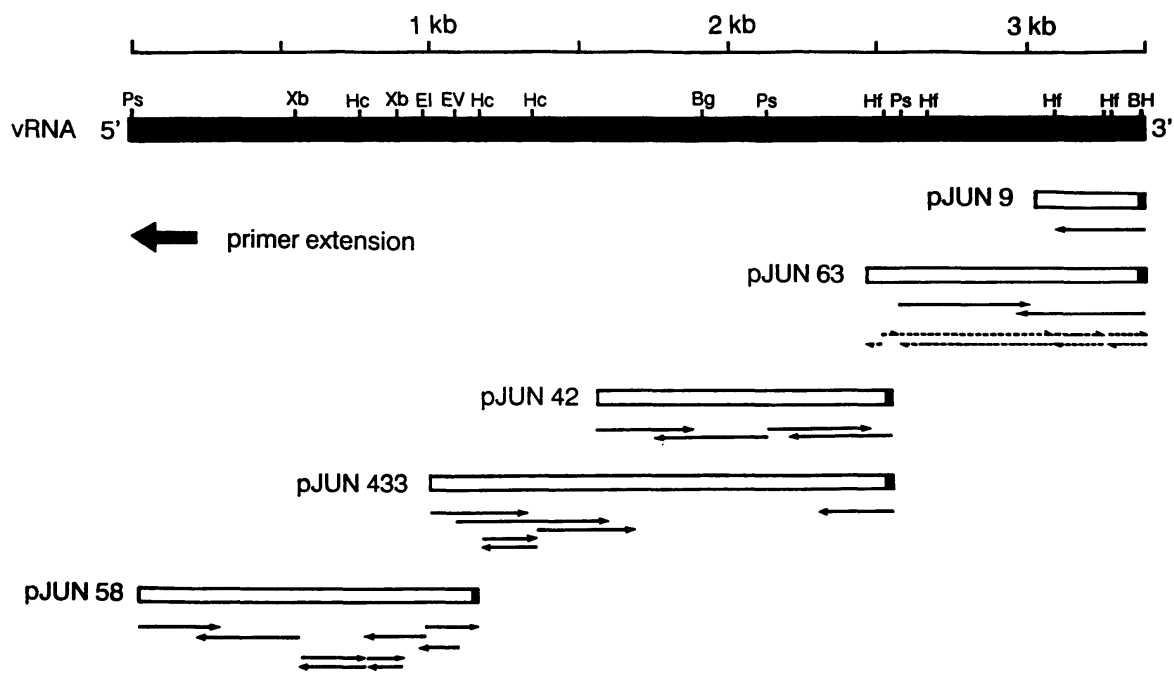

FIGURE 1. Cloning and sequencing strategy of Junin virus S RNA. The sequence of $S$ RNA nucleotide is represented in the viral sense with a size scale in kilobases above. Some of the overlapping clones spanning the entire S RNA are shown as rectangles. Phosphorylated synthetic oligonucleotides that were used to prime cDNA synthesis are indicated as black boxes at the beginning of each clone. Subcloning into $\mathrm{Ml} 3 \mathrm{mpl}$ and $\mathrm{mpl}$, using the restriction sites that are indicated, was performed in order to generate the nucleotide sequence data by the method of Sanger $e t$ al. (1977). The sequences were obtained using a modified T7 DNA polymerase (Sequenase ${ }^{\mathrm{TM}}, \mathrm{USB}$ ) as shown by the continuous arrows. A region of the sequence (nucleotides 2472-3400) determined by the chemical cleavage method of Maxam and Gilbert (1980) is indicated by dashed arrows representing the restriction fragments involved. The thick arrow indicates the 5 ' end sequence confirmed by primer extension using a synthetic oligonucleotide complementary to Junin virus $S$ RNA nucleotides 143-194 (Ghiringhelli et al., 1991). 
end. The $3^{\prime}$ end sequence of the viral RNA was deduced from primer extension products generated using intracellular viral-complementary full-length S RNA as template and was found to be coincident with the cloned cDNA sequence derived from viral genomic RNA. The $19 \mathrm{nu}-$ cleotides at the $3^{\prime}$ terminus were identical to the direct RNA sequence data derived for other arenaviruses by Auperin et al. (1982). This analysis showed that the complete $S$ RNA sequence comprised 3400 nucleotides with a base ratio of $26.6 \% \mathrm{~A}, 21.0 \% \mathrm{G}, 23.8 \% \mathrm{C}$, and $28.6 \% \mathrm{U}$ (Fig. 2) (Ghiringhelli et al., 1991).

The analysis of the nucleotide sequence indicates the existence of two nonoverlapping long open reading frames of opposite polarities (Fig. 3). They were deduced to code for the $\mathrm{N}$ protein and GPC protein, by analogy to the other arenaviruses and confirmed by Western blot analyses of recombinant products using bacterial and eukaryotic expression systems (Rivera-Pomar et al., 1990, 1991; Romanowski et al., unpublished results). One open reading frame, in the viral-complementary

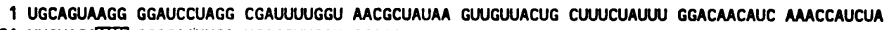
81 UUGUACAUU⿴囗十 GGGCAAUUCA UCAGCUUCAU GCMGAAAUA CCUACCUUUU UGCAGGAMGC UCUGAAUAUU GCUCUUGUUG 161 CAGUCAGUCU CAUUGCCAUC AUUAAGGGUG UAGUAAACCU GUACAMAAGU GGUUGUUCM UUCUUGAUCU AGCAGGMGG 241 UCCUGCCCGA GAGCUUUUAA AAUCGGACUG CACACAGAGG UUCCAGACUG UGUCCUUCUU CAAUGGUGGG UCUCUUUUUC 321 CAACAUUCCA CAUGACCUGC CUCUGUUGUG UACCUUAAAC AAGAGCCAUC UUUACAUUAA GGGGGGCAMU GCUUCAUUCA 401 AgAUCAGCUU UGAUGACAUC GCAGUGUUGU UACCAGAAUA UGACGUUAUA AUUCAGCAUC CGGCAGAUAU GAGCUGGUGU 481 UCUAAAAGUG AUGAUCAAAU UAGGCUGUCU CAGUGGUUCA UGAAUGCUGU GGGGCAUGAU UGGUAUCUAG ACCCACCAUU 561 UCUGUGUAGG AACCGUACAA AGACAGAAGG CUUCAUCUUU CAAGUCAAUA CCUCCAAGAC UGGUAUCAAU GRMTCUAUG 641 CCAAGAAGUU UAAGACUGGU AUGCACCAUU UAUAUAGAGA AUACCCCGAC UCUUGCUUGG AUGGCAAACU GUGUUUGAUG 721 AAGGCACAAC CCACCAGUUG GCCUCUCCAA UGUCCACUUG ACCAUGUCAA CACAUUACAU WUCCUCACAM GAGGCAAGAA 801 CAUUCAGCUU CCAAGGAGGU CUUUAAAAGC AUUCUUUUCC UGGUCUCUGA CAGACUCAUC CGGCAGGAC ACCCCUGGAG 881 GCUAUUGUCU. AGAAGAGUGG AUGCUCGUUG CAGCCAAAAU GAAGUGUUUU GGCAAUACUG CUGUAGCAAA AUGCAAUCUG 961 AAUCAUGACU CUGAAUUCUG UGACAUGCUG AGGCUUUUUG AUUACAACAA AAAUGCUAUC AMAACCUUAA AUGAUGAAAC 1041 UAAGMACAA GUAAAUCUGA UGGGACAGAC AAUCAAUGCG CUGAUAUCUG ACAAUUUAUU GAUGAAAAC MMAAUUAGGG 1121 aAUUGAUGAG UGUCCCUUAC UGCAAUUACA CAAAAUUUUG GUAUGUCAAC CACACACUUU CAGGACAACA CUCAUUACCA 1201 AgGUGCUGGU UAAUAAAAAA CAACAGCUAU UUGAaCAUUU CUGACUUCCG UAAUGACUGG AUACUAGAAA GUGACUUCUU 1281 aAUUUCUGAA AUGCUAAGCA AAGAGUAUUC GGACAGGCAG GGCAAAACUC CCUUGACUUU AGUUGACAUC UGUUUUUGGA 1361 GCACAGUAUU CUUCACAGCG UCCCUCUUCC UUCACUUGGU GGGCAUACCC ACCCAUAGGC ACAUCAGAGG CGAGGCAUGC 1361 GCACAGUAUU CUUCACAGCG UCCCUCUUCC UUCACUUGGU GGGCAUACCC ACCCAUAGGC ACAUCAGAGG CGAGGCAUGC 1521 CAGAGGACAC UAAGACCUCC CGAAGGUCCC CACCAGCCCG GGCAUUGCCC GGGCUGGUGU GGCCCCCCAG UCCGCGGCCU 1601 GGCCGCGGAC UGGGGAGGCA CUGDUUACAG UGCAUAGGCU GCCUUCGGGA GGAACAGCAA GCUCGGUGGU AAUAGAGGUG 1681 UAAGUUCUUC UUCAUAGAGC UUCCCAUCCA ACACUGACUG AAACAUUAUG CAGUCUAGCA GAGCACAGUG UGGCUCACUG 1761 GAGGCCAACU UAAAGGGAGC AUCCUUAUCU CUCUUUUUCU UGCUGACAAC CACUCCAUUG UGAUGUUUGC AUAGGUGGCC 1841 AAAUUUCUCC CAGACCUGUU GGUCGAACUG CCUGGCUUGU UCUGAUGUAA GCCUAACAUC MACCAGCUUA AGAUCUCUUC 1921 UUCCAUGGAG GUCAAACAAC UUCCUGAUGU CAUCGGACCC UUGAGUGGUC ACAACCAUGU CCGGAGGCAG CAAGCCAAUC 2001 ACGUAACUAA GAACUCCUGG CAUUGCAUCU UCUAUGUCUU UCAUUAAGAU GCCGUGAGAG UGUCUGCUAC CAUUUUUAAA 2081 CCCUUUCUCA UCAUGUGGUU UUCUGAAGCA GUGAAUAUAC UUGCUACCUG CAGGCUGGA CMACGCCAUC UCAACAGGG 2161 CAGUAGCUGG UCCUUCAAUG UCGAGCCAAA GGGUAUUGGU GGGGUCGAGU UUCCCCACUG CCUCUCUGAU GACAGCUUCU 2241 UGUAUCUCUG UCAAGUUAGC CAAUCUCAAA UUCUGACCGU UCUUUUCCGG UUGUCUAGGU CCAGCAACUG GUUUCCUUGU 2321 CAGAUCAAUA CUUGUGUUGU CCCAUGACCU GCCUAUGAUU UGUGAUCUGG AACCAAUAUA AGGCCAACCA UCGCCAGAAA 2401 GGCAAAGUUU GUACAGAAGG UUUUCAUAAG GGUUUCUAUU GCCUGGUUUC UCAUCAAUAA ACAUGCCUUC UCUUCGUUUA 2481 ACCUGAAUGG UUGAUUUUAU GAGGGAAGAA AAGUUAUCUG GGGUGACUCU GAUUGUCUCC MACAUAUUUC CAUCAUCAAG 2561 AAUGGAUGCA CCAGCCUUUA CUGCAGCUGA AAGACUAAAG UUGUAGCCAG AMAUGUUGAU GGAGCUUUCA UCCUUAGUCA 2641 CAAUCUGGAG GCAGUCAUGU UCCUGAGUCA AUCUGUCAAG GUCACUCAAG UUUGGAUACU UCACAGUGUA UAGAAGCCCA 2721 AGAGAGGUUA AAGCCUGUAU GACACUGUUC AUUGUCUCAC CUCCUUGAAC AGUCAUGCAU GCAAUUGUCA AUGCAGGAAC 2801 AGAACCAAAC UGAUUGUUAA CUUUUGAAGG AUCUUUAACA UCCCAUACCC UCACCACACC AUUUCCCCCA GUUCCUUGCU 2881 GUUGAAAUCC CAGUGUUCUC AAUAUCUCUG AUCUCUUGGC CAGUUGUGAC UGAGACAAGU UACCCAUGUA MACCCCUUGA 2961 GAGCCUGUCU CUGCUCUUCU AAACUUGGUU UUUAAAUUCC CAAGGCCAGA CGCCAACUCC AUCCGCUCAA CCCUCCCCAG 3041 AUCUCCCGCC UUGAAAACCG UGUUUCGUUG AACACUCCUC AUGGACAUGA GUCUGUCAMC CUCUUUAUUC AGGUCCCUCA 3121 ACUUAUUGAG GUCUUCUUCC CCCCUUUUAG UCUUUCUGAG UGCCCGCUGC ACCUGUGCCA CUUGGUUGAA GUCAAUGCUG 3201 UCAGCAAUUA GCUUGGCAUC CUUCAGAACA UCCGACUUGA CAGUCUGAGU AAAUUGACUC MAACCUCUCC UUAAGGACUG 3281 AGUCCAUCUA AAGCUUGGAA CCUCUUUGGA GUGUGOCAUS CCAGAAGAUC UGGUGGUUUU GAUCUGAGAA AAAAUUGCUC 3361 AGUGAAAGUG UUAGACACUA UGCCUAGGAU CCACUGUGCG
}

FIGURE 2. Nucleotide sequence of Junin virus S RNA. The 3400-nucleotide-long sequence of the genome or viral S RNA of Junin virus is presented and the orientation of the open reading frames corresponding to the GPC and N genes is indicated by arrows on the sides. The translational initiation and termination codons of GPC and the corresponding anticodons of $\mathrm{N}$ (encoded in the viral-complementary sequence) are boxed. The inverted repeats at the intergenic region are underlined. 


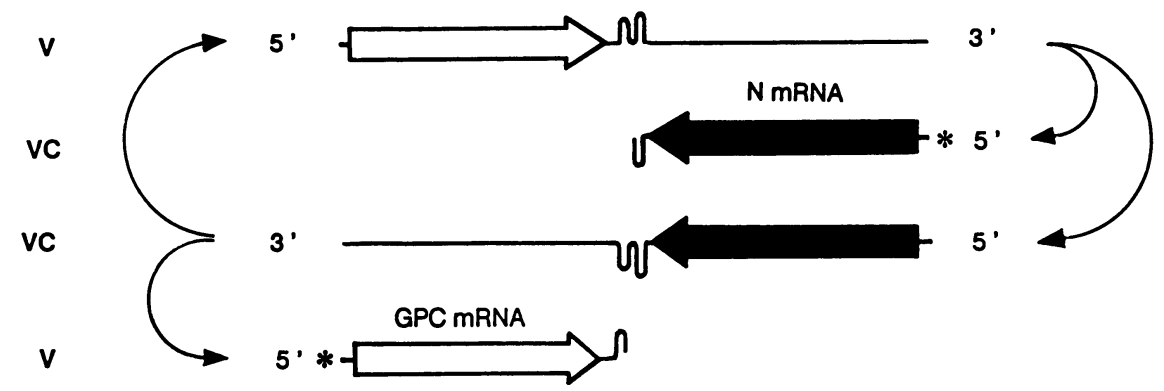

FIGURE 3. Schematic of the gene arrangement in Junin virus S RNA. The "ambisense" $S$ RNA of Junin virus is shown divided into a negative $(-)$ and positive $(+)$ region encoding the $\mathrm{N}$ gene in the $(-)$ or viral complementary $(\mathrm{VC})$ and the GPC gene in the $(+)$ or viral (genomic) polarity RNA (V). The open reading frames corresponding to the $\mathrm{N}$ and GPC genes are shown as filled and open rectangles, respectively, with arrowheads indicating the direction of translation. The subgenomic mRNAs (correlating well with size and polarity detected in cytoplasmic RNA of infected cells) are also shown, the asterisks indicating nontemplated nucleotide sequences at their $5^{\prime}$ ends (Rivera-Pomar, 1991). The thin curved arrows indicate explicitly the template-transcript relationships among the different RNA species.

(vc) RNA sequence, extends from nucleotides 82-84 (AUG) to nucleotides 1774-1776 (UAA) and codes for the nucleocapsid protein, $\mathrm{N}$ (Fig. 4, Ghiringhelli et al., 1989). The other open reading frame, encoding the GPC (glycoprotein precursor) in the viral genome-sense (v) RNA sequence starts at positions 88-90 (AUG; CAU vc sequence residues 3310-3312) and stops at positions 1531-1533 (UAA, UUA vc sequence residues $1867-1869$, Fig. 7 ).

\section{B. The Nucleocapsid Protein Gene (N)}

The first AUG in the vc S RNA at positions $82-84$ is probably the true initiation codon for the $\mathrm{N}$ protein. Examination of the surrounding nucleotide sequences indicates that this AUG is placed in a favorable context (CTGGCAUGG) according to the consensus nucleotides identified by Kozak $(1978,1984)$ as the most frequent flanking sequence for eukaryotic translation initiation codons (i.e., $\mathrm{CC}_{A}^{\mathrm{G}} \mathrm{CC}$ AUG G). The 1692-nucleotides-long open reading frame specifies a polypeptide of 564 amino acids with a molecular weight of 63,033 daltons, in good agreement with the estimates based on electrophoretic mobility (Martinez Segovia and De Mitri, 1977; Grau et al., 1981). Assuming, for simplicity, the charge of amino acids at neutral $\mathrm{pH}$ for $\mathrm{K}$ or $\mathrm{R}$ as +1 , for $\mathrm{H}$ as +0.5 , and for $\mathrm{D}$ and $\mathrm{E}$ as -1 , the $\mathrm{N}$ protein has a net charge of +14.5 . Although most of the positively charged amino acid residues are scattered throughout the protein sequence, some clustering of Ks and/or Rs may be noted. A strongly positive KKKR center is located at amino acid 


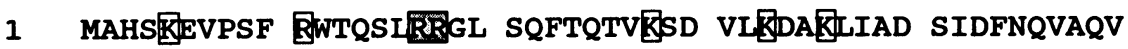

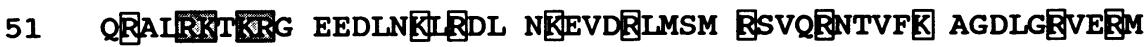

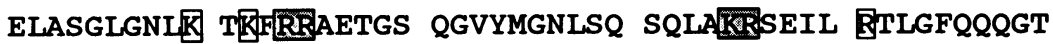

151

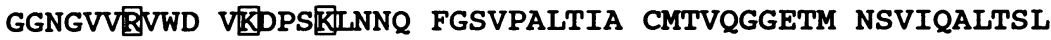

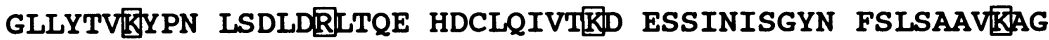

251 ASILDDGNML ETIRVTPDNF SSLI区STIQV ERREGMFIDE KPGNENPYEN

301 LLY《LLCLSGD GWPYIGSRSQ IIGRSWDNTS IDLTRWPVAG PRQPERNGQN

351 IRLANLTEIQ EAVIREAVG囷 LDPTNTLWLD IEGPATDPVE MALFQPAGS

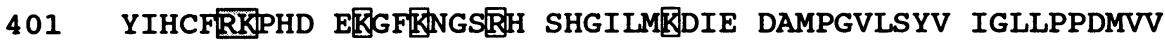

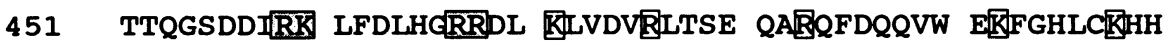
501

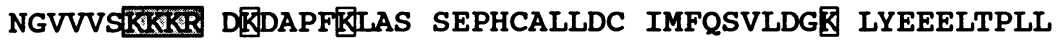
551 PPSLLFLP国A AYAL*

FIGURE 4. Amino acid sequence of Junin virus $\mathrm{N}$ protein. Translation product of the $\mathrm{N}$ ORF from Fig. 2. The basic amino acid residues $K$ and $R$ are boxed and clusters of two, three, and four such residues are shaded.

residues 507-510, a triple basic KRR sequence at amino acid positions 281-283, and nine groups of two basic $\mathrm{K}$ and/or $\mathrm{R}$ residues.

The relatively high frequency of positively charged amino acid residues in the $\mathrm{N}$ protein sequence conforms well to the idea of interaction with the negatively charged RNA in the viral nucleocapsids. However, no homology to the eukaryotic RNP consensus sequence was found (Dreyfuss et al., 1988). It has also been suggested that $\mathrm{N}$ could play a role in the regulation of the transcription/replication process during arenavirus infection (Ghiringhelli et al., 1991; Iapalucci et al., 1991). On the other hand, there is some evidence that $\mathrm{N}$-derived polypeptides can enter the cell nucleus (Young et al., 1987). The essence of a nuclear targeting sequence appears to be a short run of basic amino acids such as those found in Junin virus $N$ residues $507-510$ or 55-59 (Hunt, 1989). However, this sequence, while probably necessary, is not sufficient to ensure nuclear entry. At the present time, the nuclear targeting of $\mathbf{N}$ requires further investigation.

The alignment of the amino acid sequences of the $\mathrm{N}$ gene products of Junin and Tacaribe viruses reveals a sequence identity as high as $76 \%$. If the same comparison is made with other New World and Old World arenaviruses the sequence homologies fall within the range of 53-47\% 

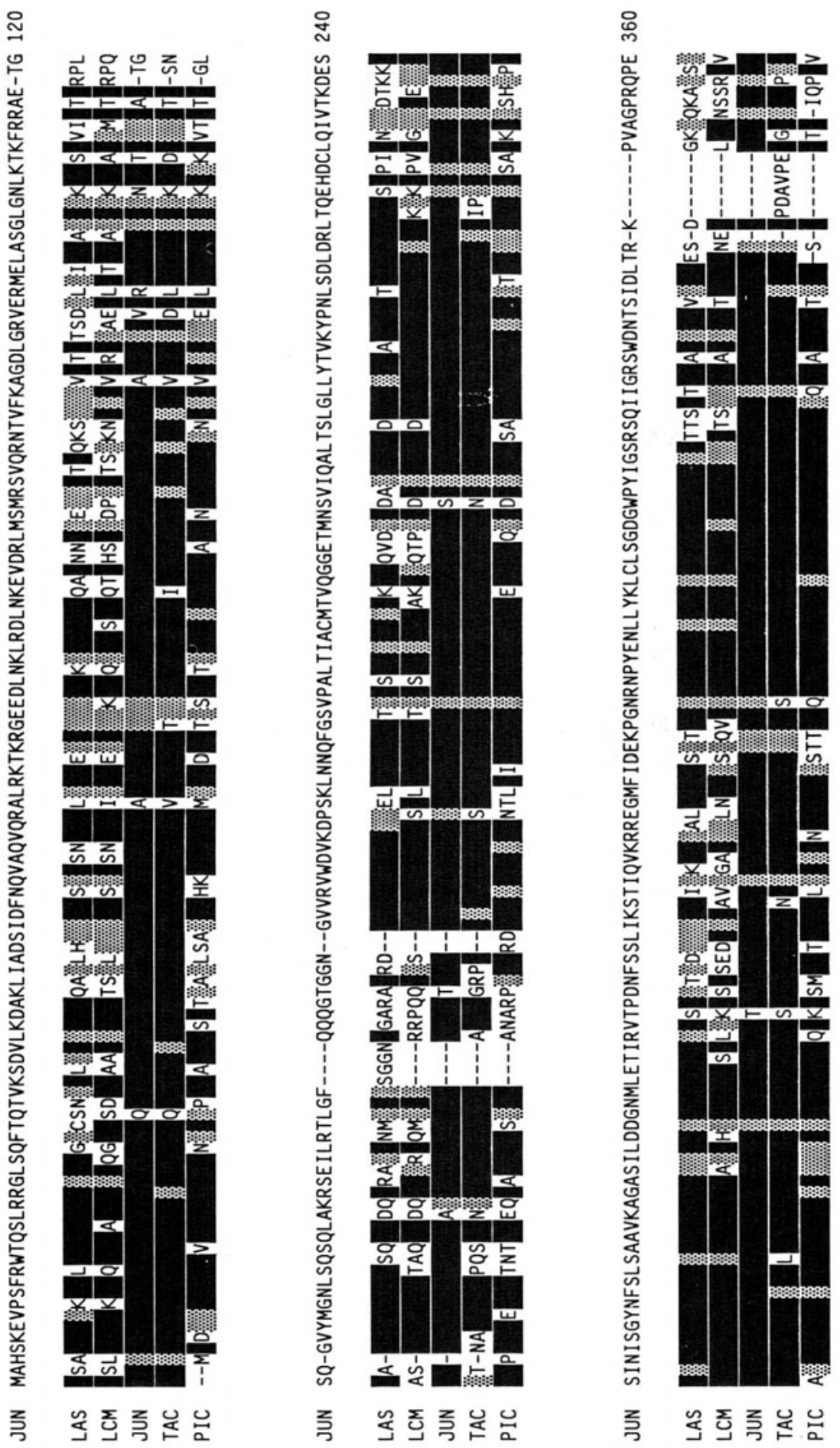

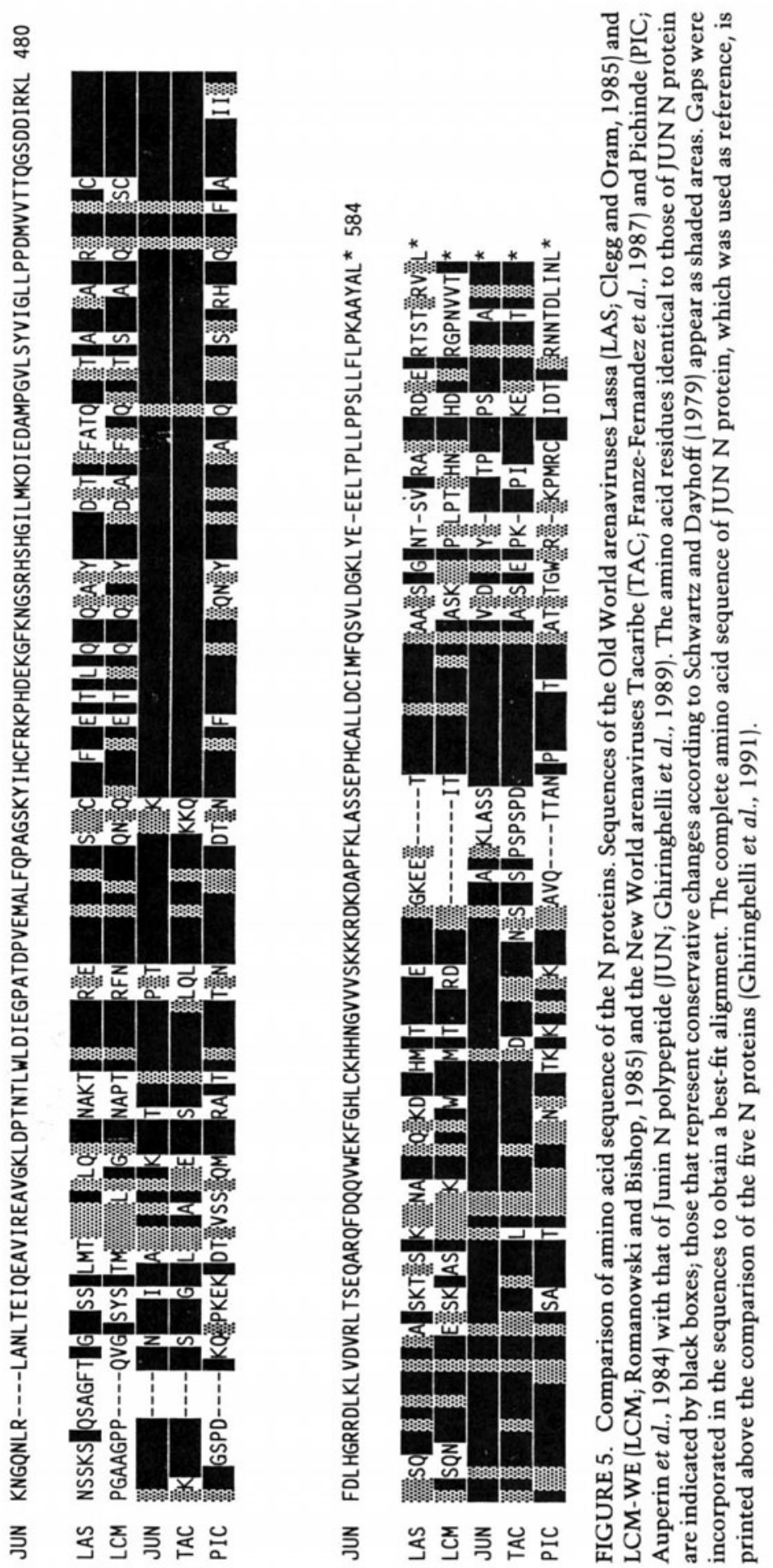
TABLE II. Amino Acid Sequence Homology of Arenavirus Structural Polypeptides

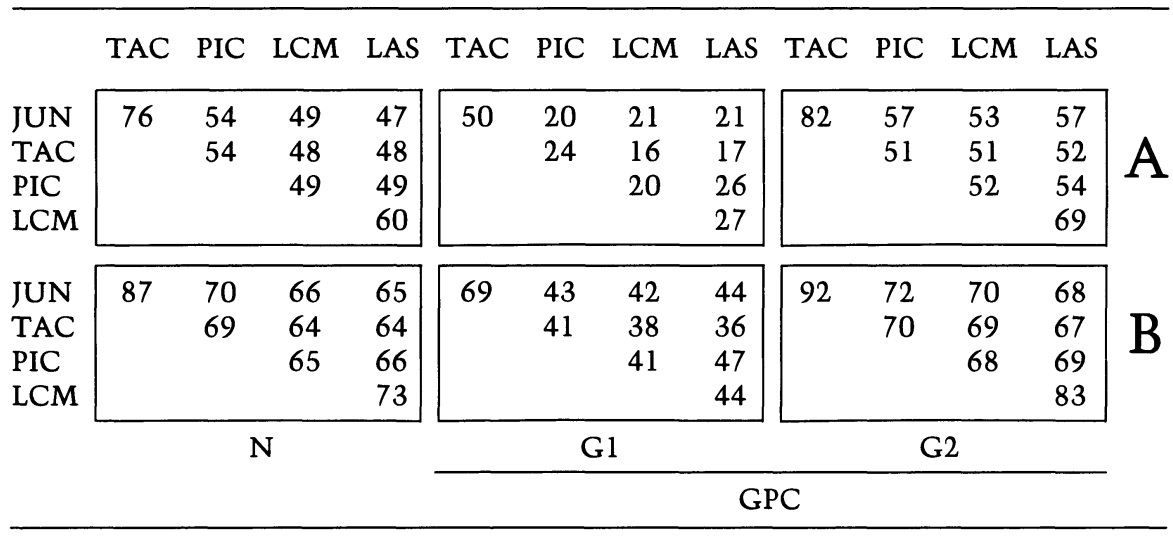

(A) The figures represent the percentages of amino acid identities obtained by the comparison between the different arenavirus proteins. Gaps were introduced in the amino acid sequences of pairs of homologous proteins to produce a best-fit alignment, but conservative changes were not considered for the calculation of homology percentages (the names of the different arenaviruses are abbreviated as in Fig. 5). N: nucleocapsid protein. The amino acid sequence of the glycoprotein precursor (GPC) was formally divided into the amino-terminal half $G 1$ and the carboxy-terminal half $G 2$. The cleavage site demonstrated for LCM virus GPC and the homologous sequences in the other arenaviruses were used to formally define the G1 and G2 regions (see Fig. 8).

(B) Sequence homology (\%) including conservative changes according to Schwartz and Dayhoff (1979).

(Fig. 5 and Table II). These homology figures do not take into account substitutions representing amino acid residues with similar biochemical characteristics (e.g., R-K, D-E, V-I, etc.). In addition, the conservation of many cysteine $(C)$, glycine $(G)$, and proline $(P)$ residues suggests that the three-dimensional structures of the arenavirus $\mathrm{N}$ proteins are more conserved than indicated by simple comparison of their primary structures. The amino acid sequence similarities between the $\mathrm{N}$ proteins are in agreement with the monoclonal antibodies cross-reactivities reported by Howard et al. (1985), Sanchez et al. (1989), and Buchmeier et al. (1981). In particular, the outstanding degree of cross-reactivity between Junin and Tacaribe viruses is highlighted by the percentage of sequence homology in Table II.

\section{Expression of the Nucleocapsid Protein Gene in Transfected Cells}

When the cloned genes for the nucleocapsid proteins of Junin and LCM viruses were inserted into an SV40-derived expression vector and transfected into BHK-21 and CV-1 cells, the transient expression yielded a polypeptide biochemically and immunologically identical to the $\mathrm{N}$ protein synthesized during viral infection (Rivera-Pomar et al., 1991). The $\mathrm{N}$ polypeptide was detected by indirect immunofluorescence 
in $5-20 \%$ of the cells, so that the rest of the cells could be used as internal negative controls. The level of expression of Junin and LCM virus nucleocapsid protein in these transfected cells was found to be roughly similar to that observed in infected BHK-21 and CV-1 cell lines. Therefore, one would expect the $\mathrm{N}$ protein synthesized in the transfected cell to behave in a manner similar to that observed in virus-infected cells (Weissenbacher and Damonte, 1983).

A cytoplasmic localization was determined for the $\mathrm{N}$ polypeptide expressed in cells transfected with Junin as well as LCM virus $\mathrm{N}$ genes. There are some reports of the nucleocapsid protein found in the nucleus of Pichinde virus-infected cells (Young et al., 1987) and in the membrane of L cells infected with LCM virus (Zeller et al., 1986, 1988). However, Rivera-Pomar et al., (1990, 1991) could not demonstrate these localizations either for the transfected cells or for the infected ones. The patterns of immunofluorescence are variable and match those found in cells infected with these arenaviruses, i.e., varying from diffuse cytoplasmic staining to granules either distributed throughout the cytoplasm or concentrated in the perinuclear region. In particular, a speckled pattern of immunofluorescence has been observed coincident with previous reports on arenavirus-infected cells (Weissenbacher and Damonte, 1983).

These studies suggest that $\mathrm{N}$ protein is associated with basophilic granules. Such basophilic particles have previously been described in infected cells as part of the cytopathic effect (Bruno-Lobo et al., 1968; Weissenbacher and Damonte, 1983). The above mentioned association is possibly related to the biochemical properties of the polypeptides, exhibiting clusters of basic amino acids (Romanowski and Bishop, 1985; Ghiringhelli et al., 1989 and 1991). These polypeptides might interact with cytoplasmic RNA to form ribonucleoprotein complexes.

The association of $\mathrm{N}$ protein with cytoplasmic granules that undergo rearrangements at different stages of the cell cycle suggests a behavior similar to that of a newly described group of ribonucleoprotein particles. These large virus-like structures named "vaults" have been found in the cytoplasm of higher and lower eukaryotes and reported to associate with cytoskeletal elements (Kedersha and Rome, 1990). The regular appearance of extensive granulation in the cytoplasm of $\mathrm{N}$ expressing cells suggests a possible link between the synthesis of the $\mathrm{N}$ protein and the development of the cytopathic effect (CPE) during arenavirus infection.

The use of SV40-derived expression vectors bearing the E. coli neomycin resistance gene permitted the isolation of BHK-21 and CV-1 cell lines stably expressing N. CV1 and Vero cells that expressed LCM or Junin virus $\mathrm{N}$ protein showed a marked $\mathrm{CPE}$, similar to that observed in infected cells. The CPE led to cell lysis after few days, thus preventing the isolation of stably transformed clones. On the contrary, it was possible to isolate G418-resistant clones from transfected BHK-21 cultures. 

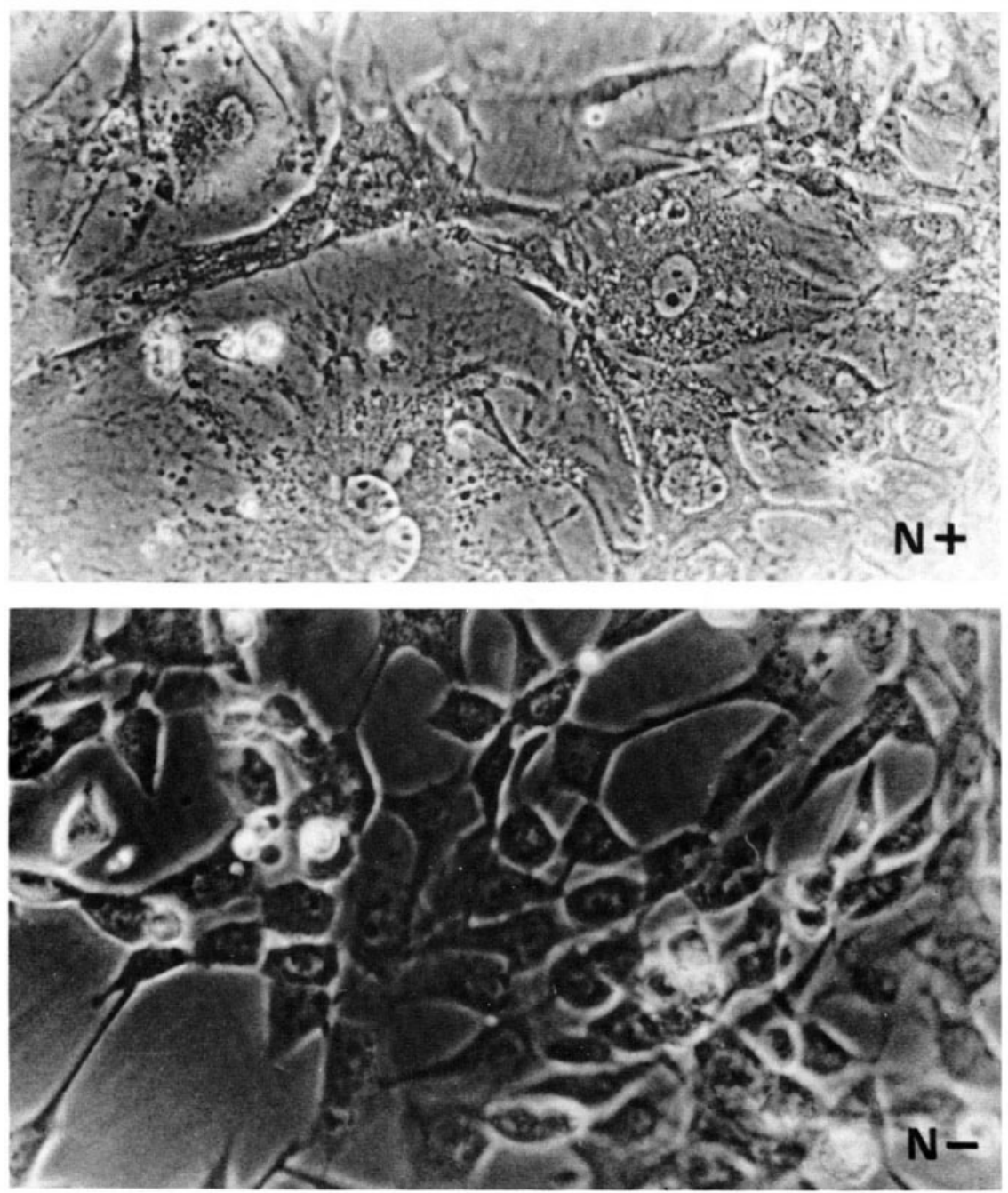

FIGURE 6. Transfected BHK-21 cells stably expressing Junin virus $\mathrm{N}$ protein. Cell monolayers were transfected with either the SV40-derived vector pKG4 or the recombinant expression plasmid pKG4-NJUN containing the N ORF of Junin virus in the appropriate orientation. Stable transfectant clones were selected using the neomycin analog G418 and propagated in selective medium. The BHK-21 cells transfected with pKG4-NJUN yielded clones where all or none of the cells expressed $\mathrm{N}$, depending on the mode of integration of the plasmids. Shown are G418-resistant BHK cells that do not express $\mathrm{N}(\mathrm{N}-)$ and those that do $(\mathrm{N}+)$. The phase-contrast micrographs $(200 \times$ magnification) were taken without prior fixation of the cell monolayers to prevent artifactual distortion of the cell morphology. Examination of fixed cells using indirect immunofluorescence detected $\mathrm{N}$ in $100 \%$ of the cells of the G418-resistant clones that exhibited altered cell morphology, such as shown in $(\mathrm{N}+)$, whereas the other G418-resistant clones that did not express $\mathrm{N}$ (such as the one in N-1, derived from pKG4 or pKG4.N JUN, had no signs of CPE (Rivera-Pomar et al., 1991; Rivera-Pomar, 1991). 
BHK-21 clones expressing the $\mathrm{N}$ gene showed cytoplasmic granulation, vacuolization, polykaryosis, and altered cell shape (Fig. 6; Rivera-Pomar et al., 1990, 1991). Further studies will improve our understanding of the mechanisms leading to these dramatic changes in cell morphology.

\section{The Glycoprotein Precursor Gene (GPC)}

The first AUG codon of the viral-sense S RNA of Junin virus is found at 88-90 nucleotides from the $5^{\prime}$ end. Its flanking nucleotides (i.e., GUACAAUGG) match the consensus purine residue at position -3 and the $G$ at +4 , observed in all arenavirus genes, and also contain one of the $\mathrm{C}$ residues identified in the upstream region of Kozak's most frequent flanking sequence to eukaryotic translation initiation codons (Kozak, 1984). A second AUG is found within the next seven codons in frame with the first one, but lacking the $G$ at position +4 and the $A$ or $G$ at position -3 . Therefore, the first AUG triplet is deduced to be the initiating codon for a 481-amino-acids long polypeptide.

The calculated molecular weight of the GPC gene product (i.e., 55,126 daltons) is smaller than the molecular weight determined by gel electrophoresis for the intracellular glycoprotein precursor (De Mitri and Martinez Segovia, 1985; Rustici, 1984). The cotranslational glycosylation renders an obvious explanation to this experimental observation. Eight potential N-linked glycosylation sites are found in the GPC sequence (Fig. 7). Whether all are actually used for attachment of carbohydrate side chains is not known. However, one should note that four of the potential glycosylation sites are conserved among all the arenavirus GPC genes analyzed to date (Fig. 8), suggesting their functional relevance. When all the available amino acid sequences of arenavirus GPC genes are compared, it is found that the region proximal to the carboxylterminus contains a high proportion of homologous stretches, while the amino-terminal sequences diverge considerably (see Fig. 8, Table II). However, if Junin virus GPC gene product is compared to the homologous protein of Tacaribe virus, it is noticed that the first 40 amino acids from the amino-terminus are conserved with just five amino acid substitutions, only two of which could be considered nonconservative changes (i.e., Ala for Cys, Thr for Ile).

Recently, a live Junin virus vaccine, named Candid 1, was developed to control AHF. The GPC gene of this highly attenuated virus was cloned and sequenced, and its ORF was compared to the homologous regions in the S RNA of the wild-type $M C 2$ strain. The nucleotide changes concentrate in the $\mathrm{NH}_{2}$-proximal (20 nucleotide changes) and the $\mathrm{COOH}$-proximal (19 nucleotide substitutions) regions. However, major changes in the amino acid sequence occur only in the aminoterminal region of GPC as a result of several insertions and deletions in the nucleotide sequence affecting codons 43-80. After proteolytic cleav- 
1 MGQFISFMQE IPTFLQEALN IALVAVSLIA IIKGVVNLYK SGCSILDLAG

51 RSCPRAFKIG LHTEVPDCVL LQWWVSFSNN PHDLPLLCTL MKSHLYIKGG

101 NASFKISFDD IAVLLPEYDV IIQHPADMSW CSKSDDQIRL SQWFMNAVGH

151 DWYLDPPFLC RNRTKTEGFI FQVNTSKTGI NENYAKKFKT GMHHLYREYP

201 DSCLDGKLCL MKAQPTSWPL QCPLDHVNTL HFLTRGKNIQ LPRRSLKAFF

251 SWSLTDSSGK DTPGGYCLEE WMLVAAKMKC FGNTAVAKCN LNHDSEFCDM

301 LRLFDYNKNA IKTLNDETKK QVNLMGQTIN ALISDNLLMK NKIRELMSVP

351 YCW

401 EMLSKEYSDR QGKTPLTLVD ICFWSTVFFT ASLFLHLVGI PTHRHIRGEA

451 CPLPHRLNSL GGCRCGKYPN LKKPTVWRRG H*

FIGURE 7. Amino acid sequence of Junin virus GPC gene product. The putative N-glycosylation sites are boxed; those that are also conserved among the rest of the arenavirus GPC proteins are indicated by the shaded boxes. The double basic amino acid sequence identified by Buchmeier et al. (1987) as the putative proteolytic cleavage site is underlined.

age of GPC, these alterations appear in the Gl polypeptide, which is thought to be located on the surface of the virion in association with the more internal G2 protein. Although these findings are strongly suggestive of the genetic changes that lead to an attenuated phenotype, they must be complemented with studies on the direct predecessors of Candid 1, which exhibit gradually more virulent phenotypes, in order to locate precisely the mutations responsible for attenuation.

\section{E. Proteolytic Cleavage Site for the Processing of GPC}

Most of the arenaviruses have been shown to exhibit a similar glycoprotein-processing pattern, differing only in the apparent molecular weights of the GPC precursor and the processed viral glycoproteins G1 (or GP1) and G2 (or GP2) (Buchmeier and Oldstone, 1978; Compans and Bishop, 1985; Saleh et al., 1979; Grau et al., 1981; Harnish et al., 1981; Lukashevich et al., 1985; De Mitri and Martinez Segovia, 1985; Clegg and Lloyd, 1983). However, only one structural glycoprotein (G) has been reported for Tacaribe and Tamiami virions (Gard et al., 1977; Boersma et al., 1982). This apparent discrepancy is due to the selective loss of GP1 during virus purification (see Chapter 2, this volume).

In LCM virus a mannose-rich precursor, GPC $(75 \mathrm{kDa})$ is posttrans- 

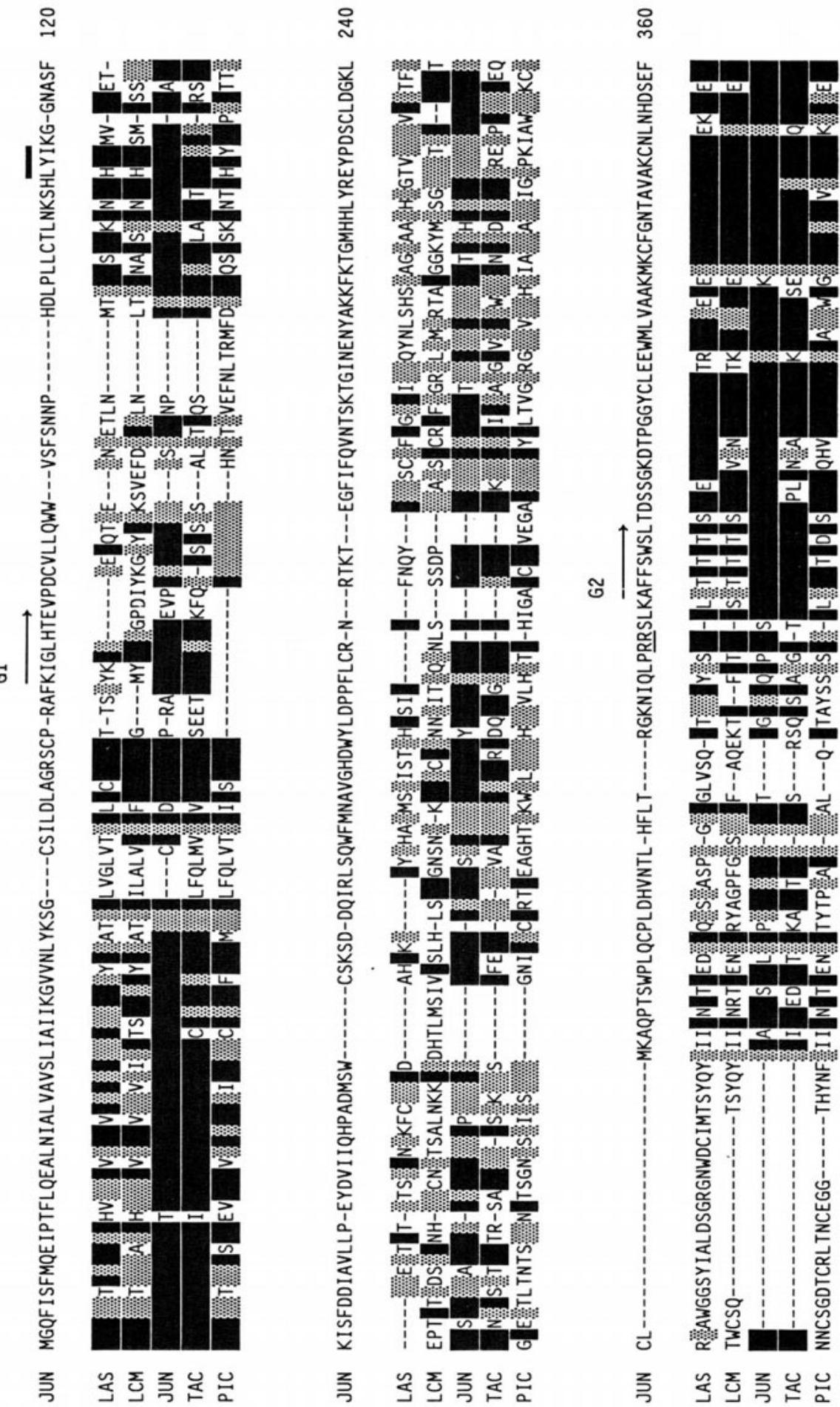


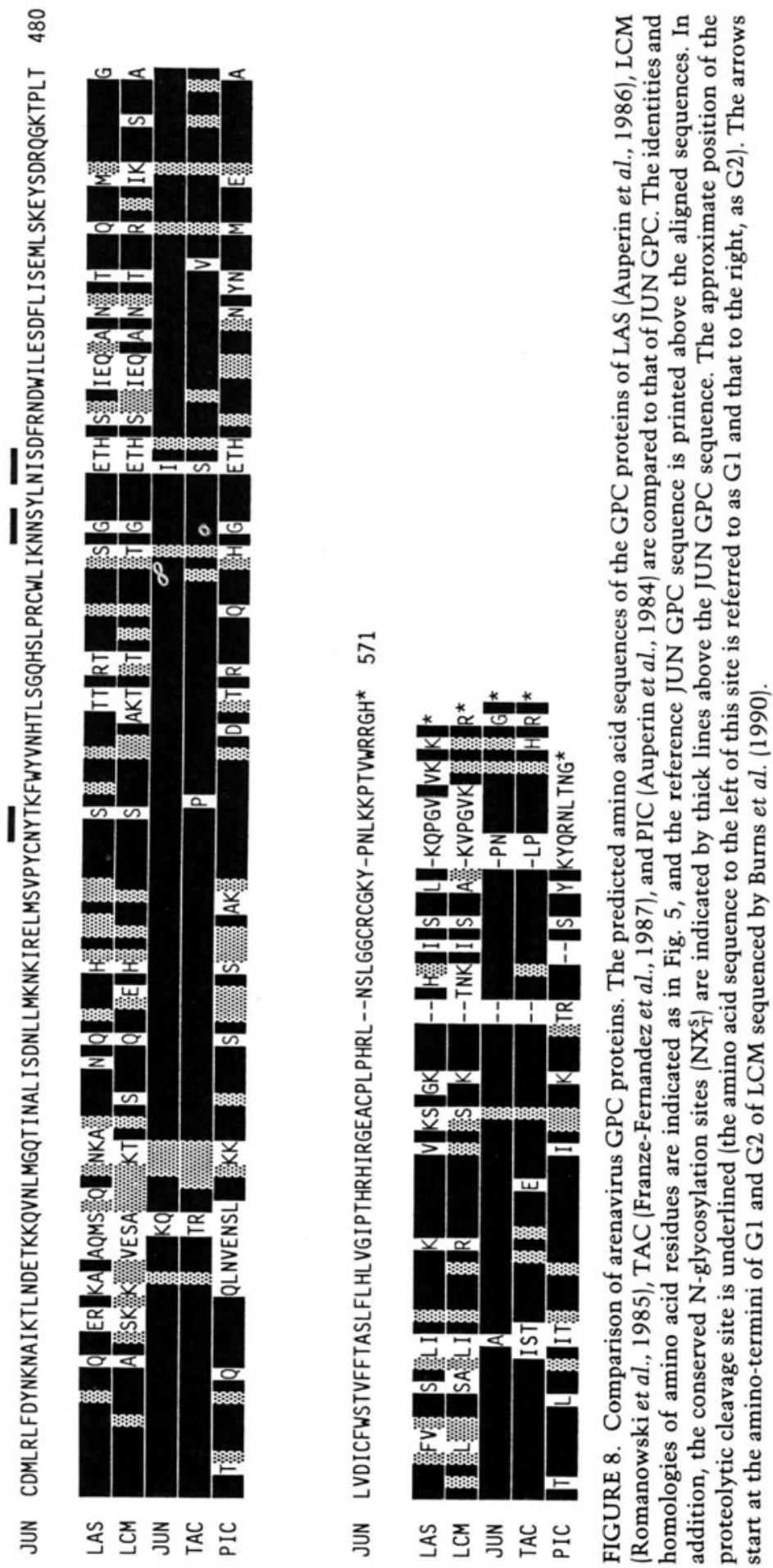


lationally modified by proteolytic cleavage and oligosaccharide processing to yield the glycoproteins GP1 (44 kDa) and GP2 (35 kDa).

Buchmeier et al. (1987) have mapped the cleavage site to be a paired basic amino acid group Arg-Arg corresponding to amino acids 262-263. This Arg-Arg pair is followed by a predominantly hydrophobic stretch of some 23 amino acids. These two features are highly conserved among the LCM (strains WE and ARM), Lassa, Pichinde, and Junin virus GPC proteins (Fig. 8). In Pichinde virus GPC the Arg-Arg pair is replaced by Arg-Lys, of similar characteristics.

The hypothesis, confirmed for LCM-ARM GPC, is that a protease of cellular origin cleaves the GPC at or near this Arg-Lys or Arg-Arg sequence generating two structural glycoproteins designated GP-1 (for LCM) or G1 (for Pichinde and Lassa) and GP-2 (for LCM) or G2 (for Pichinde and Lassa). Immunoprecipitation with antibodies raised against synthetic peptides (Buchmeier et al., 1987) and limited microsequencing of G1 and G2 tryptic peptides (Auperin et al., 1984) demonstrated that GP-1 or G1 comprises the amino-terminal half of GPC. It is also known that this protein is the antigen that elicits the synthesis of antiviral neutralizing antibodies. On the other hand, GP2 or G2 corresponds to the most conserved carboxy-terminal half of GPC. The amino terminus of GP2/G2, which would be liberated by cleavage at the ArgArg or Arg-Lys site, contains the above mentioned consensus hydrophobic sequence.

In this scenario, Junin virus major $35-\mathrm{kDa}$ glycoprotein, which elicits a neutralizing antibody response, should be homologous to LCM, Lassa, and Pichinde virus Gl protein, whereas the $44-\mathrm{kDa}$ protein could be the counterpart of G2. At this point, the functional or biological properties as well as the unambiguous sequence data should prevail over the electrophoretic mobility to designate the Junin virus glycoproteins as G1 and G2.

A particular consideration should be devoted to the comparison of Junin and Tacaribe virus glycoprotein genes. A best fit alignment of the GPC genes shows that $66 \%$ of the amino acids are conserved in identity and position. When the G1- and G2-homologous regions are analyzed separately, the percentages of amino acid sequence identity are $50 \%$ and $82 \%$, respectively. These figures are by far higher than any of the others presented in Table II.

The putative proteolytic cleavage site in Tacaribe virus GPC does not contain a doublet of basic, amino acid residues. This pair of residues is replaced by one basic amino acid ( $\mathrm{Arg}$ ) followed by a $\mathrm{Thr}$ and the consensus 23-amino-acids-long hydrophobic sequence. An alignment of this hydrophobic region with that of Junin virus places the above-mentioned $\mathrm{Arg}_{258}-\mathrm{Thr}_{259}$ pair in register with an $\mathrm{Arg}_{244}-\mathrm{Ser}_{245}$ of Junin virus GPC. The fact that Tacaribe virus GPC is proteolytically processed, together with the existence of other dibasic amino acid sequences in nonconserved regions of arenavirus GPC and N proteins, which are not 
known to be cleaved intracellularly, suggests that the double basic amino acid cluster is not an essential feature of the proteolytic target. Most likely, the protease involved in the processing of GPC requires only one basic amino acid in a sequence context that makes the particular peptide bond accessible. The sequence requirements might include all or part of the predominantly hydrophobic 23-amino-acid-long sequence conserved in all the arenaviruses, including Tacaribe (Figure 9).

\section{F. Noncoding Sequences in S RNA $5^{\prime}$ and $3^{\prime}$ Ends}

The $\mathrm{N}$ and GPC open reading frames do not overlap and account for 3135 of the total 3400 nucleotides of Junin virus S RNA. The noncoding regions upstream from the N and GPC translation initiation codons comprise 81 and 87 nucleotides, respectively. The lengths of the same regions in different arenavirus S RNAs vary, but are generally shorter than the ones described here for Junin virus.

The first 19 nucleotides at the $3^{\prime}$ end of the viral S RNA are known

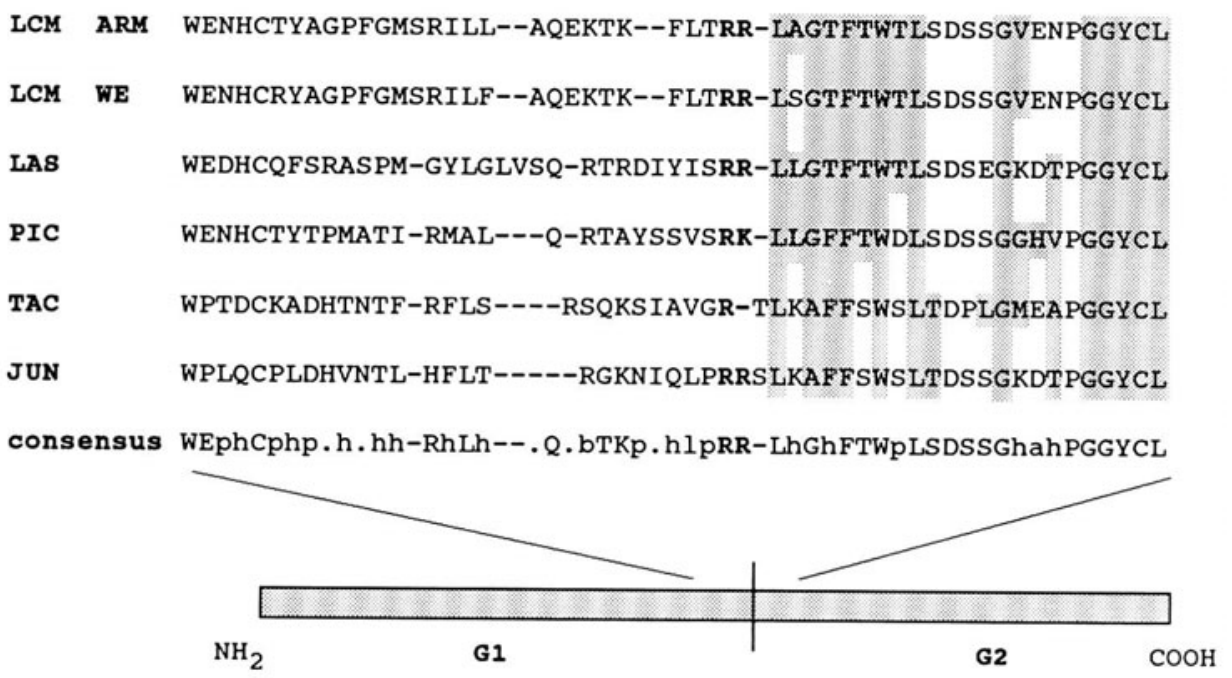

FIGURE 9. Arenavirus GPC sequence region surrounding the cleavage site (RR). The polypeptides G1 (amino-terminal half) and G2 (carboxy-terminal half) are predicted to flank the cleavage site (Buchmeier et al., 1987). The figures above the sequences indicate the amino acid residue numbers starting at the first met codon of the GPC ORF and including the gaps introduced to obtain the best-fit alignment. A consensus amino acid sequence was derived from the comparison of the aligned arenavirus GPC sequences, grouping the amino acid residues, according to Taylor (1987): hydrophobic (h), hydrophobic-aliphatic (1), charged-acidic (a), charged-basic (b), polar $(p)$; no observation is indicated by dots (.) and gaps are shown using dashes. 
to be conserved in the Arenaviridae family. This information was obtained by direct RNA sequencing of Pichinde (prototype and Munchique strain), LCM (Armstrong strain), and Tacaribe virus genomic RNA (Auperin et al., 1982), and by Maxam and Gilbert sequencing of cDNA clones derived from in vitro polyadenylated LCM (WE strain) virus S RNA (Romanowski and Bishop, 1985). The characteristic 19-nucleotide-long $3^{\prime}$ terminal sequence was also found to be conserved in Junin virus by sequencing the primer extension products complementary to the $5^{\prime}$ end of the antigenomic copy of the full-length S RNA (Rivera-Pomar, 1991).

In general, the sequence homology for the $3^{\prime}$ termini of arenavirus $S$ RNA does not extend beyond the 19 nucleotides consensus sequence. In this context, the homology between Junin and Tacaribe stands out, extending through nucleotide 53 with only six mismatches. Lassa and LCM viruses are the only other pair of arenaviruses that exhibit a sequence homology beyond the first 19 nucleotides, reaching nucleotide 34 with three mismatches (Clegg and Oram, 1985; Romanowski and Bishop, 1985).

In contrast with the conserved $3^{\prime}$ terminus, the $5^{\prime}$-terminal-most sequence of Junin virus S RNA is slightly different from the sequence conserved in Pichinde, LCM, Lassa, and Tacaribe virus (Fig. 10) (Auperin et al., 1984, 1986; Romanowski et al., 1985; Raju et al., 1990). Nevertheless, both ends can be aligned to produced a partially doublestranded secondary structure with a stabilization free energy of ca. $-58.0 \mathrm{kcal} / \mathrm{mole}$ calculated according to Tinoco et al. (1973). The fact that other arenavirus S RNA ends can be also aligned to form a homologous secondary structure is most likely related to the observation of circular forms in preparations of RNAs and nucleocapsids of Pichinde and Tacaribe virions (Vezza et al., 1978; Palmer et al., 1977). Recently, the actual existence of similar panhandle structures has been demonstrated in cross-linking experiments of influenza and La Crosse virus RNAs and nucleocapsids (Hsu et al., 1987; Raju and Kolakofsky, 1989).

On the other hand, the unexpected difference found in a region of the S RNA that was presumed to be more conserved might indicate that the viral RNA polymerase does not recognize an invariant nucleotide sequence at the $3^{\prime}$ end when viral or viral-complementary RNA is used as template. In turn, the sequence specificity could be less stringent, or the conserved panhandle secondary structure could be recognized as the RNA polymerase docking signal.

\section{G. Intergenic Region}

As mentioned in the previous sections, the coding sequences and part of the noncoding upstream regions exhibit varying degrees of nucleotide sequence homology among the different arenaviruses. How- 


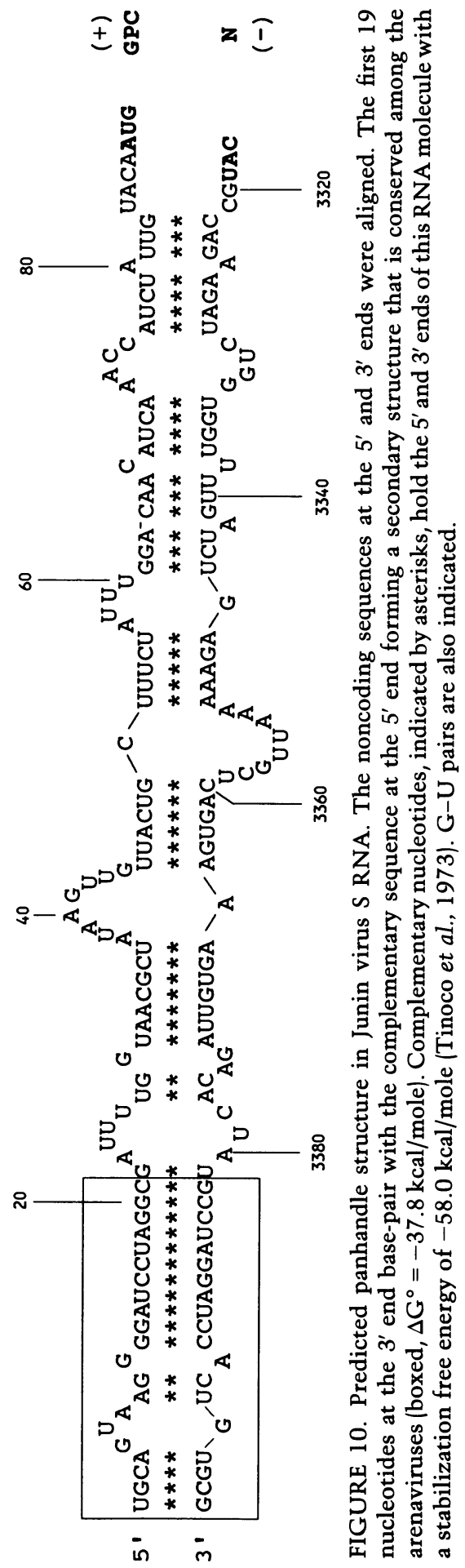


ever, no such sequence conservation can be inferred from the comparison of the noncoding region downstream from the translation termination signals of the N and GPC genes. Conversely, this intergenic region can be arranged in a relatively stable hairpin-loop structure. It is this type of secondary structure that has been conserved throughout the evolution of the arenaviruses, pointing to its functional significance (Auperin et al., 1984, 1986; Romanowski and Bishop, 1985; FranzeFernandez et al., 1987).

Junin virus exhibits two consecutive very stable hairpin structures $\left(\Delta G^{\circ}=-57.2\right.$ and $\left.-39.0 \mathrm{kcal} / \mathrm{mole}\right)$ separated by a hinge of two nucleotides instead of a single hairpin loop reported for most of the other arenaviruses (Ghiringhelli et al., 1987, 1991) (Fig. 11). However, more recently a corrected version of Tacaribe virus S RNA and that of the African arenavirus Mopeia were shown to contain also two potential hairpin-loop structures in the intergenic region (Iapalucci et al., 1991; Wilson and Clegg, 1991).

Northern blot analyses indicate that Junin virus-infected cells contain genomic and antigenomic copies of S RNA as well as subgenomic mRNAs (Fig. 3). Nevertheless, when cells are infected in the presence of protein synthesis inhibitors, only the subgenomic N mRNA is transcribed from the S RNA template (Franze-Fernandez et al., 1987; RiveraPomar, 1991). This observation and the mRNA size indicate that an antiterminator function is required for the viral RNA polymerase to synthesize a full-length copy of the S RNA, and the antiterminator function is probably supplied by the $\mathrm{N}$ protein binding to and destabilizing the intergenic hairpin structures. Although other viral or cellular proteins with high turnover rate could be alternative antiterminators, Junin

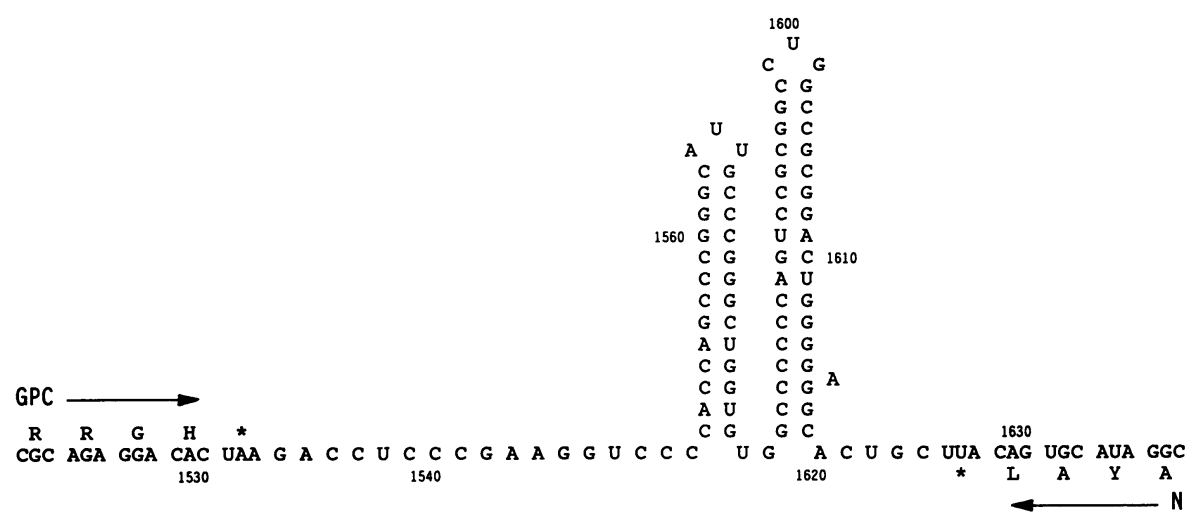

FIGURE 11. Intergenic region of Junin virus S RNA. A portion of the S RNA /nucleotides 1519-1639) comprising the ends of the GPC and N genes (sense and anti-sense strand, respectively) and the noncoding intergenic region is shown. The directions of translation are indicated by arrows, and the stop codon for the GPC protein and the stop anticodon for the $\mathrm{N}$ gene are marked with asterisks. Two potential hairpin-loop structures are stabilized by 13 and 17 base pairs $\left(\Delta \mathrm{G}^{\circ}=-39.0\right.$ and $\left.-54.2 \mathrm{kcal} / \mathrm{mole}\right)$. 
virus $\mathrm{N}$ protein contains a basic amino-acid-rich sequence (RALRKRGE) similar to those found in several RNA-binding proteins such as $\mathrm{N}$ antiterminators of phage lambda, P2 1 and P22, some ribosomal proteins, the HIV Tat, and others (Lazinski et al., 1989).

The proposed mechanism of transcription termination consists in the formation of a hairpin loop at the $3^{\prime}$ end of N mRNA, when the intergenic region is copied, leading to the release of RNA polymerase. The binding of $\mathrm{N}$ to the RNA would partially melt the RNA structure, allowing the polymerase to continue the transcription process. In this perspective, RNase protection experiments indicated that the $3^{\prime}$ termini of the subgenomic mRNAs are complementary to the first hairpin-loopforming sequence encountered by the RNA polymerase during transcription of the intergenic region. This information correlates with the proposed model, and the role of $\mathrm{N}$ is currently being evaluated using mammalian expression systems (Rivera-Pomar, 1991).

\section{CONCLUDING REMARKS}

Figure 12 shows a scheme of the organization of Junin virus S RNA based on the information presented in this chapter. Our knowledge of the molecular biology of Junin virus is still fragmentary, but cDNA cloning and sequencing of the genomic RNA have given some clarifying

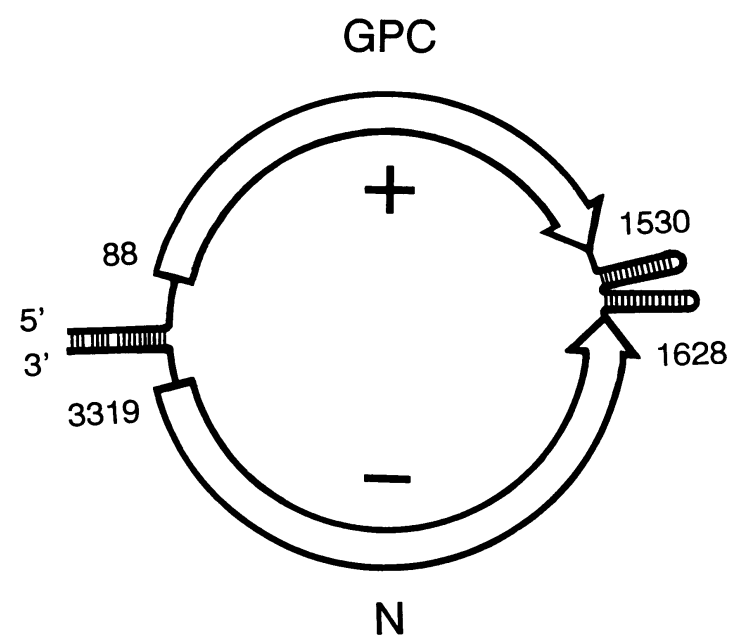

FIGURE 12. Molecular organization of Junin virus S RNA. The schematic summarizes the conclusions and predictions of the nucleotide sequence data. The nucleotide numbering starts at the $5^{\prime}$ end of the ambisense S RNA. The S RNA molecule is shown to form a circle closed by a panhandle structure $\left(5^{\prime}\right.$ and $3^{\prime}$ terminal complementary regions are not drawn to scale). The positive-sense GPC gene and the negative-sense $\mathrm{N}$ gene regions of this ambisense RNA are indicated (coding regions are shown as arrows). The double hairpin structure in the intergenic region is not drawn to scale. 
insights, raised new questions, and yielded some solutions to diagnostic problems.

The insertion of the $\mathrm{N}$ and GPC open reading frames in prokaryotic and eukaryotic expression vectors provides safe-to-handle antigens for immunoassays to be used in confirmatory AHF diagnosis or epidemiological screening studies. On the other hand, making use of the sequence data, a simplified nucleic acid amplification assay has been developed for the early and rapid detection of Junin virus RNA in clinical samples, a critical issue considering that the only effective therapy that reduces AHF mortality rate from $30 \%$ to $1 \%$ consists of treatment with immune plasma in the first few days after the onset of symptoms that are not always clear (Romanowski et al., 1991).

ACKNOWLEDGMENTS. The author acknowledges the enthusiasm and dedication with which P. D. Ghiringhelli undertook the experimental work in the molecular cloning and sequencing of Junin virus RNA. Other present and past members of the laboratory at the University of La Plata: R. V. Rivera-Pomar, M. E. Lozano, N. I. Baro, M. F. Rosas, and E. M. Manzella-also contributed, with varying inputs, to the cDNA cloning of the genome of Junin virus. The author would also like to kindly acknowledge the encouragement and continuous support of Dr. O. Grau. Finally, S. A. Moya deserves special thanks for her careful work at the word processor.

The project was financially supported by Grants PID 3916301/85, PID 3053700/88 from CONICET, 349-0275/86 from SECYT, 1348/85 from CIC BA (Argentina), and DAMD 17-89-Z-9024 from USAMRDC (USA). The author is a career investigator of CONICET and Adjunct Professor of Biological Chemistry at the University of La Plata.

\section{REFERENCES}

Anón, M. C., Grau, O., Martínez Segovia, Z. M., and Franze-Fernández, M. T., 1976, RNA composition of Junin virus, $J$. Virol. 18:833.

Aribalzaga, R. A., 1955, Una nueva enfermedad epidémica a germen desconocido: Hipertermia nefrotóxica, leucopénica y enantemática, Día Médico 27:1204.

Auperin, D. D., Compans, R. W., and Bishop, D. H. L., 1982, Nucleotide sequence conservation at the $3^{\prime}$ termini of the virion RNA species of New World and Old World arenaviruses, Virology 121:200.

Auperin, D. D., Romanowski, V., Galinski, M. S., and Bishop, D. H. L., 1984, Sequencing studies of Pichinde arenavirus S RNA indicate a novel coding strategy, an ambisense viral S RNA, J. Virol. 52:987.

Auperin, D. D., Sasso, D. R., and McCormick, J. B., 1986, Nucleotide sequence of the glycoprotein gene and intergenic region of the Lassa virus S genome RNA, Virology 154:155.

Bishop, D. H. L., Gould, K. G., Akashi, H., and Clerx-Van Haaster, C. M., 1982, The complete sequence and coding content of snowshoe hare bunyavirus small (S) viral RNA species, Nucleic Acids Res. 10:3703. 
Boersma, D. P., Saleh, F., Nakamura, K., and Compans, R. W., 1982, Structure and glycosylation of Tacaribe viral glycoproteins, Virology 123:452.

Boxaca, M. C., Parodi, A. S., Rugiero, H., and Blay, R., 1961, Fiebre hemorrágica experimental en el cobayo (virus Junin), Rev. Asoc. Argent. Biol. 37:170.

Boxaca, M. C., Guerrero, L. B. de, Parodi, A. S., Rugiero, H. R., and Gonzalez Cappa, S., 1965, Viremia en enfermos de fiebre hemorragica argentina, Rev. Asoc. Med. Argent. 79:230.

Bruno-Lobo, G. G., Bruno-Lobo, M., Johnson, K. M., Webbs, P. A., and De Paola, V., 1968, Pathogenesis of Junin virus infection in the infant hamster, An. Microbiol. (Rio de Janeiro) 15:11.

Buchmeier, M. J., and Oldstone, M. B. A., 1978, Identity of the viral protein responsible for serological cross-reactivity among the Tacaribe complex arenaviruses, in: Negative Strand Viruses and the Host Cell (B. J. W Mahy and R. D. Barry, eds.), pp. 91-97, Academic Press, New York.

Buchmeier, M. J., Lewicki, H. A., Tomori, O., and Oldstone, M. B. A., 1981, Monoclonal antibodies to Lymphocytic choriomeningitis and Pichinde viruses: generation, characterization and cross-reactivity with other arenaviruses, Virology 113:73.

Buchmeier, M. J., Southern, P. J., Parekh, B. S., Wooddell, M. K., and Oldstone, M. B. A., 1987, Site-specific antibodies define a cleavage site conserved among arenaviruses GP-C glycoproteins, I. Virol. 61:982.

Burns, J., Salvato, M., and Buchmeier, M. J., 1990, Molecular architecture of lymphocytic choriomeningitis virus. VIII International Congress of Virology (Berlin), abstract W3001, p. 27.

Carter, M. F., Biswal, N., and Rawls, W. E., 1973, Characterization of nucleic acid of Pichindé virus, $J$. Virol. 11:61.

Casals, J., Buckley, S. M., and Cedeno, R., 1975, Antigenic properties of the arenaviruses, Bull WHO 52:421.

Clegg, J. C. S., and Lloyd, G., 1983, Structural and cell-associated proteins of Lassa virus, $I$. Gen. Virol. 64:1127.

Clegg, J. C. S., and Oram, J. D., 1985, Molecular cloning of Lassa-virus RNA: Nucleotide sequence and expression of the nucleocapsid protein gene, Virology 144:363.

Compans, R. W., and Bishop, D. H. L., 1985, Biochemistry of arenaviruses, Curr. Top. Microbiol. Immunol. 114:153.

Coto, C. E., and Parodi, A. S., 1968, Purificacion del virus Junin (FHA) a partir de cerebro de raton infectado, Rev. Soc. Argent. Biol. 44:77.

Coto, C. E., and Vombergar, M. D., 1969, The effect of 5-iododeoxyuridine and actinomycin D on the multiplication of Junin virus, Arch. Ges. Virusforsch. 27:307.

Coto, C. E., Help, G. I., and Tkaczevski, L. Z., 1972, Biological properties of Junin virus purified from infected mouse brain, Medicina (Buenos Aires) 32:281.

Cresta, B., Padula, P., and Martinez Segovia, Z. M., 1980, Biological properties of Junin virus proteins. I. Identification of the immunogenic glycoprotein, Intervirology 13:284.

De Mitri, M. I., and Martinez Segovia, Z., 1980, Biological activities of Junin virus proteins. II. Complement fixing polypeptides associated with the soluble antigen and purified virus particles, Intervirology 14:84.

De Mitri, M. I., and Martinez Segovia, Z. M., 1985, Polypeptide synthesis in Junin virusinfected BHK-21 cells, Acta Virologica 29:97.

Dreyfuss, G., Swanson, M. S., and Pinol-Roma, S., 1988, Heterogeneous nuclear ribonucleoprotein particles and the pathway of mRNA formation, Trends Biochem. Sci. 13:86.

Dutko, F. J., Wright, E. A., and Pfau, C. J., 1976, The RNAs of defective interfering Pichinde virus, J. Gen. Virol. 31:417.

Farber, F. E., and Rawls, W. E., 1975, Isolation of ribosome-like structures from Pichinde virus, J. Gen. Virol. 26:21.

Franze-Fernandez, M. T., Zetina, C., Iapalucci, S., Lucero, M. A., Boissou, C., Lopez, R., 
Rey, O., Daheli M., Cohen, G., and Zalein, M., 1987, Molecular structure and early events in the replication of Tacaribe arenavirus S RNA, Virus Res. 7:309.

Gangemi, J. D., Rosato, R. R., Connell, E. V., Johnson, E. M., and Eddy, G. A., 1978, Structural polypeptides of Machupo virus, J. Gen. Virol. 41:183.

Gard, G. P., Vezza, A. C., Bishop, D. H. L., and Compans, R. W., 1977, Structural proteins of Tacaribe and Tamiami virions, Virology 83:85.

Ghiringhelli, P. D., Rivera, R., Baro, N., Grau, O., and Romanowski, V., 1987, Molecular cloning of Junin virus RNA. VII International Congress of Virology (Edmonton, Canada), abstract OP3.10, p. 253.

Ghiringhelli, P. D., Rivera-Pomar, R. V., Baro, N. I., Rosas, M. F., Grau, O., and Romanowski, V., 1989, Nucleocapsid protein gene of Junin arenavirus (cDNA) sequence, Nucleic Acids Res. 17:8001.

Ghiringhelli, P. D., Rivera-Pomar, R. V., Lozano, M., Grau, O., and Romanowski, V., 1991, Molecular organization of Junin virus S RNA: Complete nucleotide sequence, relationship with the other members of Arenaviridae and unusual secondary structures, J. Gen. Virol. 72:2129.

Grau, O., Franze-Fernández, M. T., Romanowski, V., Rustici, S. M., and Rosas, M. F., 1981, Junin virus structure, in: The Replication of Negative Strand Viruses (D. H. L. Bishop and R. W. Compans, eds.), pp. 11-14, Elsevier, North Holland.

Gubler, U., and Hoffman, B. J., 1983, A simple and very efficient method for generating cDNA libraries, Gene 25:263.

Harnish D., Dimock, K., Leung, W. C., and Rawls, W., 1981, Immunoprecipitable polypeptides in Pichinde virus-infected BHK-21 cells, in: The Replication of Negative Strand Viruses (D. H. L. Bishop and R. W. Compans, eds.), pp. 23-29, Elsevier, New York.

Help, G. I., Coto, C. E., and Tkaczevski, L. Z., 1970, Evaluacion de un metodo de purificacion del virus Junin, Medicina (Buenos Aires) 30:15.

Howard, C. R., Lewicki, H., Allison, L., Slater, M., and Buchmeier, M. J., 1985, Properties and characterization of monoclonal antibodies to Tacaribe virus, I. Gen. Virol. 66:1385.

Hsu, M., Parvin, J. D., Gupta, S., Krystal, M., and Palese, P., 1987, Genomic RNAs of influenza viruses are held in a circular conformation in virions and in infected cells by a terminal panhandle, Proc. Natl. Acad. Sci. USA 84:8140.

Hunt, T., 1989, Cytoplasmic anchoring proteins and the control of nuclear localization, Cell 59:949.

Iapalucci, S., López, R., Rey, O., López, N., Franze-Fernández, M. T., Cohen, G. N., Lucero, M., Ochoa, A., and Zakin, M. M., 1989a, Tacaribe virus L gene encodes a protein of 2210 amino acid residues, Virology 170:40.

Iapalucci, S., Lopez, N., Rey, O., Zakin, M. M., Cohen, G. N., and Franze-Fernandez, M. T., 1989b, The $5^{\prime}$ region of Tacaribe virus L RNA encodes a protein with a potential metal binding domain, Virology 173:357.

Iapalucci, S., Lopez, N., and Franze-Fernandez, M. T., 1991, The $3^{\prime}$ end of the Tacaribe arenavirus subgenomic RNAs, Virology 182:269.

Johnson, K. M., Webb, P. A., and Justines, G., 1973, Biology of Tacaribe-complex viruses, in: Lymphocytic Choriomeningitis Virus and Other Arenaviruses (F. LehmannGrube, ed.), pp. 241-258, Springer, Berlin.

Kedersha, N. L., and Rome, L. H., 1990, Vaults: Large cytoplasmic RNPs that associate with cytoskeletal elements, Mol. Biol. Rep. 14:121-122.

Kiley, M. P., Tomori, O., Regnery, R. L., and Johnson, K. M., 1981, Characterization of the arenaviruses Lassa and Mozambique, in: Replication of Negative Strand Viruses (D. H. L. Bishop and R. W. Compans, eds.), pp. 11-14. Elsevier-North Holland, New York.

Kozak, M., 1978, How do eukaryotic ribosomes select initiation regions in messenger RNA? Cell 15:1109. 
Kozak, M., 1984, Compilation and analysis of sequences upstream from the translational start site in eukaryotic mRNAs, Nucleic Acids Res. 12:857-872.

Lascano, E. F., and Berria, M. I., 1970, Microscopia electronica de cultivos primarios de fibroblastos de raton inoculados con virus Junin, Medicina (Buenos Aires) 29:487.

Lascano, E. F., and Berria, M. I., 1974, Ultrastructure of Junin virus in mouse whole brain and mouse brain tissue culture, $J$. Virol. 14:965.

Lazinski, D., Grzadzielska, E., and Das, A., 1989, Sequence-specific recognition of RNA hairpins by bacteriophage antiterminators requires a conserved arginine-rich motif, Cell 59:207.

Leung, W. C., and Rawls, W. E., 1977, Virion-associated ribosomes are not required for the replication of Pichinde virus, Virology 81:174.

Lopez, R. A., Grau, O., and Franze-Fernandez, M. T., 1986, Effect of actinomycin D on arenavirus growth and estimation of the generation time for a virus particle, Virus Res. 5:213.

Lukashevich, T. S., Lemeshko, N. N., Stelmakh, T. A., Golubev, V. P., and E. P. Stcheslenok, 1985, Some biochemical properties of Lassa virus RNA and polypeptides, Med. Microbiol. Immunol. 175:73.

Maiztegui, J. I., and Sabattini, M. S., 1977, Extensión progresiva del área endémica de fiebre hemorrágica argentina, Medicina (Buenos Aires) 37(Suppl. 3):162.

Maiztegui, J. I., Laguens, R. P., Cossio, P. M., Casanova, M. B., de la Vega, M. T., Ritacco, V., Segal, A., Fernández, N. J., and Arana, R. M., 1975, Ultrastructural and immunohistochemical studies in five cases of Argentine hemorrhagic fever, I. Infect. Dis. 132:35.

Maiztegui, J. I., Feuillade, M., and Briggiler, A., 1986, Progressive extension of the endemic area and changing incidence of AHF, Med. Microbiol. Immunol. 175:149.

Mannweiler, K., and Lehmann-Grube, F., 1973, Electron microscopy of LCM virus-infected L cells, in: Lymphocytic Choriomeningitis Virus and Other Arenaviruses (F. Lehmann-Grube, ed.), pp. 37-48, Springer, Berlin.

Martinez Segovia, Z. M., and De Mitri, M. I., 1977, Junin virus structural proteins, I. Virol. 21:579.

Martinez Segovia, Z. M., and Diaz, A., 1968, Purification of Junin virus by an aqueous biphasic polymer system, Appl. Microbiol. 15:1602.

Martinez Segovia, Z. M., and Grazioli, F., 1969, The nucleic acid of Junin virus, Acta Virol. 13:264.

Martinez Segovia, Z. M., Holstein, B. A., and Grazioli, F., 1967, Multiplicacion del virus Junin en cultivo de tejidos, Cie. Investi. 23:35.

Martinez Segovia, Z. M., De Mitri, M. I., and Berdesky, S., 1974, Nutritional requirements for Junin virus production in BHK cultured cells, Acta Physiol. Lat. Am. 24:656.

Maxam, A., and Gilbert, M., 1980, Sequencing end-labeled DNA with base specific chemical cleavages, in: Methods in Enzymology (L. Grossman and K., Moldave, eds.), Vol. 65, pp. 499-560, Academic Press, New York.

Mettler, N. E., Buckley, S. M., and Casals, J., 1961, Propagation of Junin virus, the etiological agent of Argentine hemorrhagic fever, in HeLa cells, Proc. Soc. Exp. Biol. Med. 107:684.

Mettler, N. E., Casals, J., and Shope, R. E., 1963, Study of antigenic relationship between Junin virus, the etiological agent of Argentinian hemorrhagic fever, and other arthropod-borne viruses, Am. J. Trop. Med. Hyg. 12:647.

Murphy, F. A., and Whitfield, S. G., 1975, Morphology and morphogenesis of arenaviruses, Bull. WHO 52:409.

Murphy, F. A., Webb, P. A., Johnson, K. M., Whitfield, S. G., and Chappel, W. A., 1970, Arenaviruses in Vero cells: Ultrastructural studies, J. Virol. 6:507.

Palmer, E. L., Obijeski, J. F., Webb, P. A., and Johnson, K. M., 1977, The circular segmented nucleocapsid of an arenavirus: Tacaribe virus, J. Gen. Virol. 36:541.

Parodi, A. S., Greenway, D. J., Rugiero, H. R., Rivero, E., Frigerio, M. J., Mettler, N. E., 
Garzon, F., Boxaca, M., Guerrero, L. B. de, and Nota, N. R., 1958, Sobre la etiologia del brote epidemico en Junin, Dia Med. 30:2300.

Pederson, I. R., 1973, Different classes of ribonucleic acids isolated from lymphocytic chorimeningitis virus, $J$. Virol. 11:416.

Pfau, C. J., Bergold, G. H., Casals, J., Johnson, K. M., Murphy, F. A., Pedersen, I. R., Rawls, W. E., Rowe, W. P., Webb, P. A., and Weissenbacher, M. C., 1974, Arenaviruses, Intervirology 4:207.

Pirosky, I., Zuccarini, J., Molinelli, E. A., Di Pietro, A., Martini, P., Ferreyra, B., Gutman Frugone, L. F., and Vazquez, T., 1959, Virosis hemorrágica del noroeste bonaerense. Endemoepidémica, febril, enantemática y leucopénica. I. La primera inoculación experimental al hombre, Orient. Med. 8:144.

Raju, R., and Kolakofsky, D., 1989, The ends of La Crosse virus genome and antigenome RNAs within nucleocapsids are base paired, $I$. Virol. 63:122.

Raju, R., Raju, L., Hacker, D., Garcin, D., Compans, R., and Kolakofsky, D., 1990, Non templated bases at the $5^{\prime}$ ends of Tacaribe virus mRNAs, Virology 174:53.

Ramos, B. A., Courtney, R. J., and Rawls, W. E., 1972, The structural proteins of Pichinde virus, I. Virol. 10:661.

Rawls, W. E., and Leung, W-C., 1979, Arenaviruses, in: Comprehensive Virology (H. Frankel-Conrat and R. Wagner, eds.), Vol. 14, pp. 157-192, Plenum Press, New York.

Rivera-Pomar, R. V., 1991, Análisis molecular del gen de la proteina de la nucleocápside del virus Junin, Doctoral thesis, Facultad de Ciencias Exactas, Universidad Nacional de La Plata, Argentina.

Rivera-Pomar, R. V., Manzelia, E. M., Ghiringhelli, P. D., Grau, O., and Romanowski, V., 1990, Expression of the arenavirus nucleocapsid protein: its possible role in the development of cytopathic effect. VIIIth International Congress of Virology, Berlin, Abstract W3-005.

Rivera-Pomar, R. V., Manzella, E. M., Ghiringhelli, P. D., Grau, O., and Romanowski, V., 1991, Patterns of transient expression of the arenavirus nucleocapsid protein gene in transfected cells, Microscop. Electron. Biol. Cel. 15:41.

Romanowski, V., 1981, Estructura bioquimica del virus Junin, Doctoral thesis, Facultad de Ciencias Exacta Universidad Nacional de La Plata, Argentina.

Romanowski, V., and Bishop, D. H. L., 1983, The formation of arenaviruses that are genetically diploid, Virology 126:87.

Romanowski, V., and Bishop, D. H. L., 1985, Conserved sequences and coding of two strains of lymphocytic choriomeningitis virus (WE and ARM) and Pichinde arenavirus, Virus Research 2:35.

Romanowski, V., Matsuura, Y., and Bishop, D. H. L., 1985, Complete sequence of the S RNA of lymphocytic choriomeningitis virus (WE strain) compared to that of Pichinde arenavirus, Virus Research 3:101.

Romanowski, V., Lozano, M. E., Ghiringhelli, P. D., and Grau, O., 1991, A simple nucleic acid amplification assay for the early and rapid detection of Junin virus in clinical specimens, International Conference on Negative Strand Viruses, Charleston, SC.

Rosas, M. F., 1984, Bioquimica de virus: estructura de la envoltura del virus Junín, Doctoral thesis, Facultad de Ciencias Exactas, Universidad Nacional de La Plata, Argentina.

Rosas, M. F., Romanowski, V., and Grau, O., 1988, The phospholipid composition of arenaviruses, Anal. Asoc. Quim. Argent. 76:269.

Rowe, W. P., Pugh, W. F., Webb, P. A., and Peters, C. J., 1970a, Serological relationships of the Tacaribe complex of viruses to lymphocytic choriomeningitis virus, $J$. Virol. 5:289.

Rowe, W. P, Murphy, F. A., Bergold, G. H., Casals, J., Hotchin, J., Johnson, K. M., Lehmann-Grube, F., Mans, C. A., Traub, E., and Webb, P. A., 1970b, Arenoviruses: Proposed name for a newly defined virus group, $I$. Virol. 5:651.

Rustici, S. M., 1984, Desarrollo in vitro del virus Junin, proteinas intracelulares, Doctoral thesis, Facultad de Ciencias Exactas, Universidad Nacional de La Plata, Argentina. 
Saleh, F., Gard, G. P., and Compans, R. W., 1979, Synthesis of Tacaribe viral proteins, Virology 93:369.

Sanchez, A., Pifat, D. Y., Kenyon, R. H., Peters, C. J., McCormick, J. B., and Kiley, M. P., 1989, Junin virus monoclonal antibodies: Characterization and cross-reactivity with other arenaviruses, J. Gen. Virol. 70:1125.

Sanger, F., Nicklen, S., and Coulson, A. R., 1977, DNA sequencing with chain-terminating inhibitors, Proc. Natl. Acad. Sci. USA 74:5463.

Schwartz, R. M., and Dayhoff, M. O., 1979, in: Atlas of Protein Sequence and Structure (M. O. Dayhoff, ed.), pp. 353-358, National Biomedical Research Foundation, Washington, D.C.

Taylor, W. R., 1987, Protein structure prediction, in: Nucleic Acid and Protein Sequence Analysis (M. J. Bishop and C. J. Rawlings, eds.), pp. 285-322, IRL Press, Oxford.

Tinoco, I., Borer, P. N., Dengler, B., Levine, M. D., Uhlenbeck, O. C., Crothers, D. M., and Gralla, J., 1973, Improved estimation of secondary structure in ribonucleic acids, Nature (New Biol.) 246:40.

Vezza, A. C., Gard, G. P., Compans, R. W., and Bishop, D. H. L., 1977, Structural components of the arenavirus Pichinde, I. Virol. 23:776.

Vezza, A. C., Clewley, J. P., Gard, G. P., Abraham, N. Z., Compans, R. W., and Bishop, D. H. L., 1978, Virion RNA species of the arenaviruses Pichinde, Tacaribe and Tamiami, J. Virol. 26:485.

Weissenbacher, M. C., and Damonte, E. B., 1983, Fiebre hemorrágica argentina, in: Adel. Microbiol. Enf. Infecc. (C. Coto, J. Esparza, and R. A. de Torres, eds.), Vol. 2, pp. 119-171, Buenos Aires-Caracas.

Wilson, S. M., and Clegg, J. C. S., 1991, Sequence analysis of the S RNA of the African arenavirus Mopeia: An unusual secondary structure feature in the intergenic region, Virology 180:543.

Young, P. R., and Howard. C., 1983, Fine structure analysis of Pichinde virus nucleocapsids, J. Gen. Virol. 64:833.

Young, P. R., Chanas, A. C., and Howard, C. R., 1981, Analysis of the structure and function of Pichinde virus polypeptides, in: Negative Strand Virus (D. H. L. Bishop and R. W. Compans, eds.), pp. 11-14, Elsevier-North Holland, New York.

Young, P. R., Chanas, A. C., Lee, S. R., and Howard, C. R., 1987, Localization of an arenavirus protein in the nuclei of infected cells, J. Gen. Virol. 68:2465.

Zeller, W., Bruns, M., and Lehmann-Grube, F., 1986, Viral nucleoprotein can be demonstrated on the surface of lymphocytic choriomeningitis virus-infected cells, Med. Microb. Immunol. 175:89.

Zeller, W., Bruns, M., and Lehmann-Grube, F., 1988, Lymphocytic choriomeningitis virus. X. Demonstration of the nucleoprotein on the surface of infected cells, Virology 162:90. 